\title{
El terrorismo anarquista en la literatura española
}

\author{
Susana Sueiro SeOANE \\ Prof. Titular. Dpto. H. ${ }^{a}$ Contemporánea. UNED
}

Anarchist Terrorism in Spanish Literature

\begin{abstract}
RESUMEN
El tema del anarquismo, y en particular del anarquismo terrorista, ha estado muy presente en la literatura española. Son muchos los autores que han recreado en sus obras los atentados anarquistas de una época, la del tránsito del siglo XIX al

$X X$, que fue el periodo de la historia mundial en que más monarcas, presidentes y primeros ministros fueron asesinados. España no sólo no fue ajena a aquella impresionante oleada de atentados, sino que allí éstos se prolongaron durante más tiempo que en el resto de los países. Algunos de los más importantes escritores españoles de la época, como Blasco Ibáñez, Pío Baroja o Valle-Inclán, agudos observadores del mundo que les tocó vivir, hicieron protagonista de varias de sus obras al terrorismo anarquista. Este artículo analiza algunas de ellas, como Aurora roja, de Baroja, una novela en la que quedan expuestos los principios y las distintas tendencias del anarquismo, incluida la violenta, partidaria de la «propaganda por el hecho». El anarquismo español arraigó en las ciudades más industrializadas y cosmopolitas, con algunos atentados de gran tirón literario, como el del Liceo de
\end{abstract}

\section{SUMMARY}

The theme of Anarchism, particularly of Anarchist terrorism, has been very present in Spanish literature. Many are the authors who, in their writings, have portrayed the Anarchist terrorist attacks that took place during a specific epoch, that of the transition between the $X I X^{\underline{t h}}$ and $X X^{\text {th }}$ centuries, the period in world history when more monarchs, presidents and prime ministers were murdered. Spain was not only not alien to this impressive succession of terrorist attacks, but, furthermore, they continued for a much longer time than in other countries. Some of the most important Spanish writers of the time, such as Blasco Ibáñez, Pío Baroja or Valle-Inclán, sharp observers of the world that surrounded them, made Anarchist terrorism a theme of many of their works. This article analyses some of these, such as Baroja's Aurora Roja, a novel which exposes Anarchism's principles and different tendencies, including the violent one, supportive of 'propaganda of the deed'. Spanish Anarchism rooted in the more industrialised and cosmopolitan cities, with some attacks that influenced literature, such as that of the Liceo of Barcelona in 1893 , or the one carried out in Madrid by 
Barcelona en 1893, o el de Mateo Morral contra Alfonso XIII en Madrid el día de su boda, en 1906, temas centrales, uno y otro, de diversas obras literarias. Pero también arraigó en las zonas rurales de Andalucía, donde el movimiento reflejó cierta tendencia milenarista, con episodios especialmente destacados, como la invasión de Jerez por cientos de campesinos anarquistas en 1892, muy fielmente descrito en La Bodega, de

Blasco Ibáñez. Otros autores más contemporáneos han vuelto sobre aquellos episodios de terror y violencia social, aunque ya no formasen parte de su experiencia vivida. Un ejemplo significativo es el de Eduardo Mendoza y su La verdad sobre el caso Savolta, cuya acción transcurre en la turbulenta Barcelona de los años del pistolerismo, a finales de la primera guerra mundial. El rasgo común de todas las obras

analizadas es que están inspiradas en hechos y personajes históricos, y que están muy bien documentadas, por lo que son enormemente sugestivas para el historiador.

PALABRAS CLAVE anarquismo, terrorismo, literatura española
Mateo Morral against King Alfonso XIII on his wedding day, in 1906, both being events which are central themes in various literary works. It also rooted in the rural areas of Andalucia, where it showed a certain milenarist tendency, with outstanding episodes such as the invasion of Jerez, carried out by hundreds of Anarchist peasants in 1892, very accurately described in La Bodega, by Blasco Ibáñez. Other, more contemporary, authors have returned to these episodes of terror and social violence, even though they did not form part of their life experience. A significant example is Eduardo Mendoza and his La verdad sobre el caso Savolta which takes place in the turbulent Barcelona of the gun slinging years at the end of the First World War. The common characteristic of all the analysed writings is that they are inspired by historical events and characters, and are very well documented, being, thus, enormously suggestive to the historian.

\section{KEY WORDS}

Anarchism, terrorism, Spanish literature

El tema del anarquismo, y en particular del anarquismo terrorista, ha estado muy presente en la literatura española. Sobre todo, y no es de extrañar, son muchos los autores que han recreado en sus obras los atentados anarquistas de los años noventa del siglo XIX. Aquella década se caracterizó por una impresionante oleada de atentados anarquistas en todo el mundo. Fue el periodo en que más monarcas, presidentes y primeros ministros fueron asesinados de toda la historia ${ }^{1}$. En 1894 lo fue el presidente de Francia, Carnot; en 1898, la emperatriz Sisí de Austria; en 1900, el rey Humberto de Italia; en 1901, el presidente McKinley, de los Estados Unidos.

En España, hubo también episodios terroristas muy destacados, como el atentado fallido de Paulino Pallás contra el general Martínez Campos en Barcelona, en 1893; la bomba en el Liceo de Barcelona tan sólo unas semanas después; el

1 Richard BACH JENSEN: «The United States, International Policing and the War against Anarchist Terrorism, 1900-1914», Terrorism and Political Violence, Vol. 13, n. ${ }^{\circ} 1$ (Spring 2001). 
atentado, también con bomba, durante la procesión del Corpus en 1896, también en la ciudad condal; y el asesinato en 1897 del presidente del consejo de ministros, Cánovas del Castillo, por el anarquista italiano Angiolillo². Mientras en la mayoría de los países, los atentados tendieron a desaparecer con el cambio de siglo, en España se prolongaron durante más tiempo, con algunos casos muy notorios como los intentos de asesinar a Alfonso XIII en 1905 y $1906^{3}$.

Todos estos atentados se basaban en la doctrina de la «propaganda por el hecho". Sus partidarios creían que la realización de actos terroristas era una forma de propaganda mucho más poderosa que los discursos o los escritos. La prensa, dado el impacto y espectacularidad de estas acciones, daba a conocer la causa de la Anarquía recogiendo todos los detalles del atentado, así como las declaraciones del terrorista, su juicio y su ejecución; de esta forma, decían, se excitaba el ardor de los obreros y se aterrorizaba a la burguesía. El terrorista daba un gran ejemplo de sacrificio y abnegación al ofrecer su vida por la causa anarquista. Los autores de los atentados se convertían en héroes o mártires de la causa, especialmente los magnicidas, lo que contribuía a que surgieran emuladores dispuestos a vengar sus muertes.

El atentado del Liceo, el teatro de la ópera de Barcelona, por su enorme impacto, por el horror que produjo su carácter indiscriminado, ha tenido más tirón literario que otros. En la noche del 7 de noviembre de 1893, durante la representación del segundo acto de la ópera "Guillermo Tell», el anarquista Santiago Salvador arrojó al patio de butacas desde el quinto piso dos bombas, aquellas famosas bombas Orsini tan utilizadas por los terroristas de la época. Sólo una de ellas estalló y mató a veinte personas dejando heridas a otras veintisiete. El suceso aparece minuciosamente descrito en una novela histórica, Mariona Rebul/ ${ }^{4}$, de Ignacio Agustí, que, publicada en 1944, en plena posguerra española, tuvo un éxito enorme ${ }^{5}$. Como no podía ser de otro modo en aquellos años de férrea dictadura franquista, esta novela, que es una crónica social de la Barcelona de finales del siglo XIX, presenta a la burguesía barcelonesa bajo una luz muy positiva, azotada por el ciego terrorismo anarquista. El marido de Mariona, Joaquín Rius, es un joven heredero de una familia de la industria textil catalana de orígenes humildes, que sólo a base de trabajo honrado y dedicación constante había conseguido una gran fortuna y había llegado incluso a tener un palco en el Liceo, lugar emblemático de la burguesía catalana. Los personajes centrales de la historia son él, hom-

${ }^{2}$ Véase Ángel HERRERÍN: «España: La propaganda por la represión, 1892-1900», en Juan AVILÉS y Ángel HERRERÍN (eds.), El nacimiento del terrorismo en Occidente. Anarquía, nihilismo y violencia revolucionaria. Madrid, Siglo XXI, 2008. Véase también, Rafael NÚÑEZ FLORENCIO: El terrorismo anarquista 1888-1909. Madrid, Siglo XXI, 1983, pp. 103-139.

3 Véase Juan AVILÉS: «Contra Alfonso XIII: atentados frustrados y conspiración revolucionaria», en Juan AVILÉS y Ángel HERRERÍN (eds.), El nacimiento del terrorismo en Occidente. Anarquía, nihilismo y violencia revolucionaria. Madrid, Siglo XXI, 2008, pp. 141-158.

${ }^{4}$ Forma parte de la tetralogía La ceniza fue árbol.

${ }^{5}$ Enseguida se hizo una película dirigida por José Luis Saénz de Heredia y protagonizada por Sara Montiel. 
bre austero y aburrido; su mujer Mariona Rebull, soñadora e insatisfecha; y el amante frívolo y vividor de ésta. De fondo, la vida fabril de la ciudad en la que ha hecho irrupción un elemento nuevo, los sindicatos revolucionarios. La protagonista y su amante, que aquella fatídica noche ocupan clandestinamente un palco del Liceo, mueren en el atentado anarquista ${ }^{6}$.

Como es sabido, el anarquismo español arraigó en las ciudades más industrializadas y cosmopolitas (sobre todo en Barcelona), pero también en las zonas rurales de Andalucía, donde el movimiento reflejó cierta tendencia milenarista, con episodios especialmente destacados como la invasión de Jerez por cientos de campesinos anarquistas un año antes del atentado del Liceo. Hay una novela que refleja muy bien estos hechos: La Bodega, de Blasco Ibáñez.

Pero, antes de adentrarnos en el análisis de esta interesante obra, digamos unas palabras sobre otras novelas de Blasco que tratan también el tema anarquista, si bien de calidad literaria inferior. En los años noventa, los de la oleada de atentados, escribió Los fanáticos (1895). Como nos cuenta el experto en blasquismo, Ramiro Reig ${ }^{7}$, en ella, el autor contrapone dos extremos, el carlismo clerical y el anarquismo, personificados en «dos hermanos, hijos de un cura infame y lascivo, que se persiguen incansablemente a lo largo de la novela y terminan, como en un desastre de Goya, cayendo por un barranco, abrazados en terrible pelea. De los dos bloques narrativos, uno está dedicado a las guerras carlistas, el otro a los atentados del terrorismo anarquista, en un galimatías argumental difícil de seguir. Los carlistas son brutos ignorantes incitados por curas trabucaires; los anarquistas parecen mejor gente, obreros sin trabajo, desesperados por la miseria, pero a los que también la ignorancia lleva a creer en doctrinas utópicas y a realizar actos desalmados. Blasco establece una cierta diferencia, ya que algunos anarquistas recobran el buen sentido, pero el fanatismo los hace iguales. Santiago Salvador, el autor del atentado del Liceo, realiza la síntesis perfecta, puesto que antes de anarquista había sido carlista ${ }^{8}$. Los fanáticos fue un fracaso, quizás por lo inverosímil de la historia.

Blasco volvió a tratar el tema anarquista en La catedral (1903), metáfora del inmovilismo y del atraso de España provocado por la iglesia, que impide toda posibilidad de progreso ${ }^{9}$. La catedral (la primada de España, la de Toledo), es una mole omnipresente en la novela. Toda la acción transcurre en su interior claustrofóbico. El protagonista, Gabriel Luna, un anarquista ex seminarista (ya veremos luego a protagonistas de otras novelas que también han sido seminaristas antes de con-

\footnotetext{
6 Cuenta Agustí en sus memorias que cuando, tras la publicación de la novela, asistió a la inauguración de la temporada del Liceo, había en la sala una latente expectación, como si la gente estuviera, cincuenta años después del suceso que se narraba en la novela, pendiente de la bomba que pudiera estallar. Véase Ignacio AGUSTí: Ganas de hablar. Barcelona, Planeta, 1974.

7 Véase, Blasquistas y clericales: la lucha por la ciudad en la Valencia de 1900. Valencia, Alfons el Magnánim, 1986.

8 Ramiro REIG: Vicente Blasco Ibáñez. Espasa Calpe, 2002.

9 Véase prólogo de Luis BÉJAR de la edición de Antonio Pareja, Toledo, 2001, pp. 7-15.
} 
vertirse al anarquismo), ha combatido en mil batallas por la libertad sin vencer en ninguna; regresa a Toledo, su lugar de nacimiento, donde tenía antes de marcharse una prometedora carrera en el seno de la Iglesia, desengañado y enfermo. Allí encuentra, entre los servidores y obreros de la catedral, como el campanero, a un pequeño grupo de infelices dispuestos a escuchar sus teorías emancipadoras y renace en él la esperanza de instruirles y de hacer penetrar en ellos las sublimes ideas del anarquismo. Pero aquella gente le entiende a su manera y decide pasar a la acción desvalijando el tesoro catedralicio. Gabriel se opone y sus propios discípulos le matan. Su muerte condensa el fracaso de su vida entera ${ }^{9}$ bis.

No es ésta tampoco una buena novela, el propio autor afirmó que era una de las que menos le gustaba. Las discusiones doctrinales y los discursos explicativos e ideológicos son excesivamente prolijos, de una extensión desproporcionada.

De sus novelas de crítica social ${ }^{10}$ - La catedral, 1903; El intruso, 1904; la horda, 1905 y La bodega, 1905- es ésta última, con mucho, la más lograda, lo que, unido a que trata el tema del arraigo del anarquismo en el campo andaluz ${ }^{11}$, nos ha impulsado a dedicarle una especial atención.

\section{BLASCO IBÁÑEZ Y LA BODEGA}

La bodega descrita en la novela pertenece a la familia terrateniente de los Dupont, que lleva ya tres generaciones dedicada a la producción vinícola; en la época en que transcurre la acción - desde los últimos años de la década de los 80 hasta el invierno de 1892, en que ocurrió la revuelta de Jerez, descrita en el noveno capítulo- ya no fabrica sólo vino y coñac de jerez, sino también imitaciones de otros vinos que demanda el mercado extranjero, como oporto, madeira, marsala, etc., porque el vino de jerez ya no está tan de moda en Europa. Es, pues, una época de cierta decadencia, con menos y peor retribuidos jornales en relación con tiempos pasados de esplendor, una época de aumento del malestar en los cortijos y de proliferación de grupos organizados de filiación ácrata.

La bodega, dice Blasco, es «una ciudad industrial, sin humo, sin ruido». Describe pormenorizadamente la estructura de poder existente en ella. El viñedo cen-

9 bis Véase, Ramiro REIG (2002), op. cit.

10 Tras el ciclo de novelas valencianas, en los primeros años del siglo XX, Blasco lbáñez se instala en Madrid y emprende el ciclo de novelas «sociales» 0 «de rebeldía», como a él le gustó denominarlas. Por cierto que cada una de ellas está dedicada a una ciudad: Toledo, la ciudad levítica, en La catedral; Bilbao, la ciudad industrial, en El intruso; Madrid, la gran urbe, en La horda; y Jerez, la ciudad de los señoritos, en La bodega.

11 Ramiro REIG (2002, p. 114) señala que hay algo de injusticia en que a Blasco lbáñez se le cite siempre como el autor de La barraca y no de La bodega, una novela con una tensión dramática y un ritmo narrativo tan calculado y, a la vez, tan intenso, que se lee de un tirón. Hay una edición de Cátedra de 1998 con un estudio preliminar de F. Caudet. En 1929 Benito Perojo hizo una película, una coproducción hispano-francesa, con Concha Piquer en el papel protagonista. Véase Román GUBERN: «La versión de La Bodega de Benito Perojo», Debats, Valencia, 1999, n. ${ }^{\circ} 64-65$, pp. 199-202. 
tral, llamado Marchamalo, es, nos dice, «la moderna fortaleza feudal que mantiene a las masas en la servidumbre y la abyección». En la cima se sitúan los poderosos, los «amos», como se les llama, que quieren ser también dueños de las conciencias. El amo, creyente fervoroso, obliga a sus empleados y trabajadores a ir a misa los domingos a pesar de ser su día de descanso, expulsándoles del cortijo si no lo hacen.

El señorito ocioso, amigo de juergas desenfrenadas, está también presente en la novela en el personaje de Luis Dupont, el primo del dueño, que ocasionalmente condesciende a alternar con los braceros en el cortijo, convidándoles a vino del mejor, bajo una apariencia de paternalismo, aunque en realidad lo que pretende es explotar su confianza, emborracharles y poder aprovecharse de las campesinas ebrias $^{12}$. Sabemos lo que en realidad piensa Luis de los jornaleros, a los que llama "canalla»; en un discurso como candidato a un cargo político, ante una audiencia de clase media y alta de Jerez, arremete contra los sindicatos obreros y los huelguistas; con su habitual fanfarronería, dice tener muy claro lo que haría él con los obreros: «un poco de caridad; y después religión, mucha religión, y palo al que se desmandase».

Pero los ricos se divierten sobre todo en la ciudad, en los casinos y sociedades, como el Círculo Caballista, el centro de reunión más famoso de los propietarios de cortijos y bodegas. La ciudad, odiada por los campesinos, es el símbolo de la riqueza de los latifundistas y de la burguesía mercantil gracias al negocio del vino. En aquellos años, Jerez seguía siendo, de hecho, a pesar de la crisis, una de las poblaciones más ricas de España, con grandes fortunas; figuraba por su tributación al Estado en el tercer lugar de todas las ciudades de España.

En agudo contraste con este mundo de los «amos», Blasco describe a unos braceros mal alimentados, miserables, especialmente los que trabajan en los cortijos cerealistas y ganaderos, como el de Matanzuela en la novela. Nos habla de una situación histórica real: los jornaleros ocupados en las labores del cereal ganaban menos y vivían peor que los trabajadores de las viñas. Los braceros embrutecidos, ignorantes, "con el pensamiento petrificado», «envilecidos por miles de años de servidumbre», beben para olvidar, se embriagan para mitigar el frío, el hambre y la miseria. El vino es el símbolo de su explotación, el «veneno alcohólico» que mata sus energías y acaba con su vida prematuramente.

En la escala social de la bodega, entre los amos y los braceros, se sitúan los capataces, la familia de los Montenegro, los encargados con funciones de administración, personas de confianza de los Dupont, que de pequeños jugaban con los señoritos, que se deben a ellos porque están a su servicio, que a veces condescienden con los amos de manera servil, pero que, por venir de abajo, entienden

12 «Era un placer de patricio romano embriagar a sus clientes y esclavos con bebida de emperadores». 
muy bien la desesperación de los jornaleros; oyen hablar a éstos de rebelión y a aquéllos de represión, y se mantienen en una reserva prudente.

Como veremos que ocurre también en muchas obras de Baroja, hay en esta novela de Blasco dos historias relacionadas entre sí, una coral y otra individual. La historia coral es el relato de la gestación de una sublevación de jornaleros, que culmina con la invasión de Jerez, la ciudad odiada, en un acto de violencia colectiva ${ }^{13}$. Pero por debajo de este conflicto colectivo hay otro conflicto, también entre amos y subordinados, protagonizado por uno de los empleados de la bodega, Fermín Montenegro, en una acción particular. Fermín acaba matando a Luis Dupont en un acto de venganza individual. Cuando Luis, el señorito juerguista, viola a la hermana de Fermín, Mari Luz, aprovechándose de su embriaguez, y el patriarca de la familia Dupont sólo ofrece como solución que la muchacha se meta a monja y se niega a que se casen, único medio en que los Montenegro creen poder reparar su honra, los empleados comprenden que el egoísmo y el clasismo de los terratenientes ricos no tiene límites, que su despotismo es brutal ${ }^{14}$.

Blasco Ibáñez viajó a Jerez para ver de cerca cómo vivían los jornaleros. En mayo de 1902 acompañó a Lerroux a un mitin y, de nuevo, en julio de 1904, aprovechó, en su calidad de diputado a Cortes, para conocer algunos de los pueblos de la provincia de Cádiz. No hizo estos viajes sólo para documentarse. Blasco era un importante político republicano que, en una coyuntura de crisis del anarquismo andaluz, prácticamente desarticulado precisamente tras la represión subsiguiente a la marcha campesina sobre Jerez que relata La Bodega, quiso recabar el apoyo obrero para la causa republicana. Se entrevistó con el máximo impulsor del emergente republicanismo jerezano, el destacado líder obrero Manuel Moreno Mendoza, jornalero, sindicalista y masón, que editaba el periódico La Unión Obrera. Eco de la clase trabajadora. De hecho, esta operación de impulso del republicanismo en la provincia de Cádiz fue todo un éxito: el asociacionismo obrero de signo reformista y afín al republicanismo reclutó por entonces muchísimos adeptos y el periódico de Moreno Mendoza llegó a ser el más leído por los jornaleros de la provincia ${ }^{15}$. Sin duda, tanto los viajes de Blasco a Jerez como la propia novela, tuvieron fines políticos, lo que no obsta para que la riqueza del material histórico y sociológico de La Bodega sea muy notable.

\footnotetext{
13 Llama la atención que estudiosos de Blasco lbáñez y de su obra se equivoquen al datar la época en que transcurre la novela. Ramiro Reig afirma que Blasco se inspiró en la gran huelga que tuvo lugar en el marco jerezano en 1883 y en un intento de ocupación de la ciudad similar al descrito en la novela que se produjo en 1902 (Véase REIG, 2002, p. 115). Por su parte, el hispanista alemán Hans-Jörg Neuschäfer es poco preciso cuando asegura que el relato se sitúa «alrededor de 1900» («Blasco lbáñez, ¿un Zola libertario?. Observaciones sobre el anarquismo literario alrededor de 1900», en VV. AA.: El anarquismo español y sus tradiciones culturales. Madrid, Editorial Iberoamericana, 1995, p. 297).

14 Véase REIG (2002), p. 116.

15 Sobre la importante figura de Moreno Mendoza es imprescindible el libro de Antonio MORALES BENITEZ: Prensa, masonería y republicanismo. Manuel Moreno Mendoza (1862-1936). Ayuntamiento de Jerez, 2008.
} 
Las novelas sociales de Blasco, como las de Baroja, están muy bien documentadas. La Bodega es, en gran medida, una novela antropológica ${ }^{16}$, sociológica ${ }^{17}$ e histórica. Se habla sobre todo mucho en ella de anarquismo, un fenómeno que en el último tercio del siglo XIX hace su aparición en el campo andaluz ${ }^{18}$.

Aunque el episodio histórico concreto que se narra es la marcha de campesinos sobre Jerez de 1892, hay referencias a episodios anteriores que quedaron durante mucho tiempo impresos en la memoria colectiva, como el muy famoso de la Mano Negra, una supuesta sociedad secreta a la que se imputaron una serie de incendios de cosechas y asesinatos ${ }^{19}$. En la novela esos sucesos se recuerdan. Por ejemplo, cuando los asaltantes de Jerez llegan a la cárcel, alguien dice que allí se había dado garrote a algunos de los implicados en los hechos de la Mano Negra. Blasco se refiere al régimen de terror que habían impuesto las autoridades que, a la mínima reivindicación de los trabajadores, agitaban el fantasma de un resurgir de la Mano Negra ${ }^{20}$. Parece dar crédito a la idea de una invención o exageración por parte de las autoridades, que airearon la existencia de esa supuesta sociedad secreta al objeto de desencadenar una tremenda represión, dar garrote a unos

16 Antropológica es, por ejemplo, la descripción minuciosa de las formas de trabajo en los cortijos, los problemas de los viñedos - la plaga de la filoxera y la sustitución de la vid vieja por la nueva, americana- pero también acabamos sabiendo mucho, por poner otros ejemplos, del mundo de los caballos que a los amos les gusta coleccionar, o de cómo vive el pueblo las procesiones de Semana Santa.

17 Blasco nos ofrece un cuadro general de la situación social andaluza, del latifundismo, el absentismo e inmovilismo de los terratenientes, las duras condiciones en que trabajan y viven los obreros agrícolas, su analfabetismo, las causas del malestar social, las agitaciones campesinas, etc.

18 Juan DÍAZ DEL MORAL en su clásica obra Historia de las agitaciones campesinas andaluzas (Madrid, Alianza, 1979) inició el estudio del movimiento campesino andaluz. Manuel GONZÁLEZ DE MOLINA hizo una revisión de los tópicos sobre el jornalero andaluz y la protesta campesina en «Siete problemas de la interpretación tradicional sobre el movimiento campesino andaluz», Historia y Fuente Oral, 8, 1992, pp. 25-54.

19 En la Andalucía de entonces, como nos cuenta Blasco, no había tierras comunales ni montes públicos y los jornaleros sufrían especialmente las crisis agrícolas. En 1882 hubo un llamativo incremento del malestar campesino dadas las escasas y malas cosechas de los últimos años, con el consiguiente aumento del paro y del precio del pan. La confrontación social alcanzó su cota máxima en la provincia de Cádiz y en concreto en Jerez de la Frontera. Se extendió un cierto clima de inseguridad y de amenaza del orden existente y en ese contexto, en febrero de 1883, saltó a la luz el asunto de una supuesta organización conspirativa involucrada en incendios de cosechas y asesinatos, a raíz de lo cual se produjeron decenas de detenciones de campesinos. Sobre estos sucesos, véase Clara F. LIDA: Anarquismo y revolución en la España del siglo XIX. Madrid, Siglo XXI, 1972. Demetrio CASTRO ALFÍN: Hambre en Andalucía. Antecedentes y circunstancias de la Mano Negra. Córdoba, 1986. Jacques MAURICE: «Conflicto agrario y represión preventiva. Los procesos de Jerez en 1883. Estudios de Historia Social, 2223, 1982, pp. 239-252. Antonio LÓPEZ ESTUDILLO: Republicanismo y anarquismo en Andalucía. Conflictividad social agraria y crisis finisecular (1868-1900). Córdoba, Editorial La Posada del Potro, 2001. Enrique MONTAÑÉS: «El anarquismo en Andalucía. De la F.R.E. a la Mano Negra y el asalto campesino a Jerez», en Manuel GONZÁLEZ DE MOLINA y Diego CARO CANCELA (eds.), La utopía racional. Estudios sobre el movimiento obrero andaluz. Granada, 2001, pp. 53-79.

20 Ése es «el espantajo que los amos tienen para levantarlo como bandera», se dice en la novela. Bien sabía Blasco que, en efecto, con motivo de la marcha sobre Jerez de 1892, las autoridades y gran parte de la prensa la habían interpretado como «chispazos de la no extinta Mano Negra» (Véase El Guadalete, Jerez, 12 de enero de 1892). 
cuantos trabajadores y llevar a la cárcel y torturar a centenares. No parece faltarle razón ${ }^{21}$.

Casi diez años después de los sucesos de la Mano Negra, una noche de invierno del 8 de enero de 1892, en el mismo escenario, apareció de nuevo la violencia campesina. Desde luego, los sucesos tuvieron enorme eco en la prensa, y se publicó un folleto anónimo redactado por el anarquista Ricardo Mella titulado «Los sucesos de Jerez» del que se editaron 10.000 ejemplares $^{22}$, pero el perdurable recuerdo de aquellos hechos creo que se debió sobre todo a los capítulos que Blasco lbáñez le dedicó en su novela La bodega, escrita entre diciembre 1904 y febrero 1905, en la época más productiva del autor, que tuvo un éxito notable de crítica y que en 1924 había alcanzado una tirada de 60.000 ejemplares. Blasco sigue muy de cerca la narración de los sucesos que hizo el influyente y famoso periodista José Ortega Munilla, enviado especial del periódico liberal El Imparcial, que se desplazó de Córdoba a Jerez al enterarse de lo ocurrido.

La narración de los hechos es bastante fiel a la realidad. Hubo una gigantesca concentración de trabajadores en el inmenso llano de Caulina, a las afueras de Jerez. Procedían de todos lados, muchos eran de los pueblos de la serranía, como Grazalema, Ubrique o Bornos, pero también los había de la campiña; los había, en realidad, de casi todos los pueblos de la provincia y no eran sólo trabajadores de las viñas, sino también y sobre todo de los cortijos cerealistas. Al llegar al lugar donde se concentran y ante la ausencia del esperado jefe que había de guiarles, quedan paralizados. Finalmente, de entre todos aquellos trabajadores agrícolas, unos cientos marchan simultáneamente sobre la ciudad armados con navajas, palos y utensilios de labranza, como hoces y podaderas; sólo unos pocos llevan armas de fuego, escopetas y pistolas. La mayoría son anarquistas. En la narración, igual que en la historia real, algunos grupos de asaltantes se dirigen a la cárcel con la intención de liberar a unos compañeros detenidos el día anterior en un arresto preventivo ${ }^{23}$. En la novela, uno de los presentes, temiendo una deserción generalizada, erigido en improvisado caudillo ante la ausencia de jefes reales, grita a los hombres: «Compañeros, ja Jerez!, vamos a sacar de la cárcel a nuestros hermanos».

21 Puesto que los asesinatos obedecían a causas comunes, como el robo o la venganza, y parecían ser más bien ajustes de cuentas entre gentes del campo, cabe preguntarse si los procesos respondieron a hechos reales, o fueron producto de un montaje policial. No se han encontrado testimonios concluyentes para saber con certeza si existió o no una sociedad secreta llamada Mano Negra. Es muy probable que, en una situación de creciente politización, aumentaran los grupos anarquistas clandestinos, en cualquier caso minoritarios, que juzgaban ineficaces las concentraciones tradicionales de trabajadores ante el ayuntamiento en demanda de trabajo y se mostraban partidarios de la acción violenta, de la «propaganda por el hecho". No cabe duda, en todo caso, de que el poder político y la clase propietaria aprovecharon para llevar a cabo una fuerte represión y una persecución feroz con múltiples deportaciones y condenas de prisión y, más aún, se dictaron siete condenas de muerte que se cumplieron en junio de 1883.

${ }_{22}$ Se puede ver la reproducción del folleto en la antología de textos de Mella a cargo de Vladimiro MUÑOZ, Forjando un mundo libre. Madrid, La Piqueta, 1978, pp. 167-212.

${ }_{23}$ Véase Jacques MAURICE: El anarquismo andaluz. Campesinos y sindicalistas, 1868-1936. Barcelona, Crítica, 1989, p. 125. 
En el relato, y muy probablemente también en la historia real, entre los que invaden el centro de Jerez hay quienes tienen además la esperanza de que su acción haga prender la mecha de la revolución. Blasco pone en boca de un anarquista forastero apodado «el Madrileño», que es un personaje histórico, la siguiente frase: «nos hemos reunido para la revolución; sí, eso es, para la revolución social» ${ }^{24}$.

Blasco describe a una masa de jornaleros supersticiosos, que creen en milagros, en lo inesperado y lo maravilloso, y que pueden pasar en un momento del entusiasmo más ruidoso al fatalismo más absoluto. Una multitud desorganizada, mal armada, que sin saber bien quién les convoca ni para qué, emprende una insensata aventura, quizás con la intención de apoderarse de la ciudad e iniciar una revolución que traiga la soñada sociedad perfecta; una descripción muy similar, por cierto, a la que hizo mucho después Hobsbawm en su famoso estudio sobre los movimientos campesinos milenaristas al señalar que aquellos anarquistas del campo andaluz no sabían cómo hacer la revolución, esperaban que se hiciera sola, porque lo cierto es que ellos no tenían ni un proyecto concreto ni organización alguna $^{25}$. En el asalto a Jerez, dice Blasco, no hay organización, no llevan banderas. Además, los campesinos son tremendamente ingenuos porque creen que las tropas van a confraternizar con ellos. Blasco recoge la idea, cierta, de que alguien les había hecho creer que una parte de la guarnición de Jerez simpatizaba con el movimiento, que encontrarían complicidades en los cuarteles y que la guardia de la cárcel les abriría sus puertas al verlos llegar. En la novela, sólo algún trabajador algo más cultivado que el resto, como el «Maestrico», un muchacho que, robándole horas al sueño, intentaba aprender a leer y escribir en el cortijo, intuye que van todos al desastre: «creo —dice- que vamos mal porque marchamos a ciegas».

Desde luego, Blasco no es anarquista y se le nota cuando describe a una muchedumbre ilusa, inepta y sin coordinación, incapaz de organizar su protesta de manera eficiente; una horda de hombres toscos, algunos movidos por instintos bestiales ${ }^{26}$. Como ya hemos señalado, precisamente la intención política de esta obra era que los campesinos anarquistas del campo andaluz se pasasen a las filas del republicanismo. Desde su posición republicana, Blasco criticaba duramente la injusticia de la situación campesina en Andalucía, pero no podía sino considerar,

${ }_{24}$ Por cierto que, al llegar a la ciudad, en la dispersión, este personaje se escabulle, lo que sabemos que también ocurrió en la realidad. Algún autor (véase, por ejemplo, Hans-Jörg NEUSCHÄFER: 1995, p. 298) sostiene que se trataba de un agente provocador o confidente de la policía, razón por la cual desaparece una vez cumplido el objetivo de llevar a los braceros a Jerez.

${ }_{25}$ Véase Eric HOBSBAWM: Rebeldes primitivos: estudio sobre las formas arcaicas de los movimientos sociales en los siglos XIX y XX. Barcelona, Ariel, 1968, pp. 82-84.

${ }_{26}$ «Aquellos hombres - dice - recordaban lejanos parentescos animales. Unos tenían la faz prolongada y ósea, con grandes ojos bovinos, con gesto resignado, eran los hombres-bueyes deseosos de tenderse en el surco para rumiar sin la más leve idea de protesta, con inmovilidad solemne. Otros mostraban el hocico elástico y bigotudo, los ojos de reflejo metálico de los felinos: eran los hombres-fieras, que se estremecían dilatando las narices como si percibiesen ya el olor de la sangre. Y los más, de cuerpo negro y miembros retorcidos y angulosos como sarmientos, eran los hombres-plantas, unidos para siempre a la tierra, incapaces de movimiento y de ideas, resignados a morir en el mismo sitio». 
como por lo demás hicieron también los socialistas, descabellada, perniciosa y suicida, la intentona campesina de invadir Jerez. Las crónicas de Ortega Munilla para El Imparcial presentaban, igual que hizo Blasco en su novela, la irrupción de trabajadores agrícolas en el corazón de la próspera ciudad como una manifestación de locura colectiva ${ }^{27}$. Blasco lbáñez estaba a favor de un cambio político drástico, de la instauración de la república y de las medidas reformistas que ésta haría posibles, como la extensión de la educación o la reforma agraria. Como republicano, creía que la mayoría de los males sociales provenían de la ignorancia, el analfabetismo y la falta de instrucción. La enseñanza obligatoria, gratuita y laica, eje central del programa republicano, era para él la única forma de hacer de España un país moderno y primer paso para resolver la llamada cuestión social.

Aunque Blasco critica el ideal anarquista, al que ve como un puro ensueño, muestra no obstante cierta simpatía hacia el personaje de Fernando Salvatierra, que no es otro que Fermín Salvochea, el mítico anarquista de acción, gran apóstol de la Idea, revolucionario mesiánico, conocidísimo en Cádiz. Sólo cambia el nombre, en la novela «salva-tierra» para evidenciar su misión. Los datos biográficos que da sobre el personaje - de carácter e incluso físicos-coinciden con el personaje histórico de Fermín Salvochea. Es muy lógico que Blasco empatice con esta figura que era mítica también para los republicanos ya que Salvochea había participado activamente en la revolución de 1868 desde posiciones republicano-federales y luego había encabezado la proclamación del cantón gaditano. Sólo más tarde se había hecho anarquista y desde entonces había comprometido su vida entera a luchar a favor del Ideal.

El personaje es descrito con detalle ya en las primeras páginas de la novela, y aparece o se habla de él en otros muchos momentos a lo largo de la misma. Salvatierra, al que todos los anarquistas de la provincia veneran, vuelve a Jerez tras ocho años de reclusión en un presidio (en efecto, Salvochea cumplió larga condena en la prisión del Hacho de Ceuta). Blasco cuenta que su compromiso con la lucha contra la injusticia social es tal que jamás se enamoró de ninguna mujer, ya que su pasión humanitaria ocupó todo su tiempo. Blasco muestra a un Salvatierra/Salvochea ya viejo, que se alimenta de su propio mito, que vive ya de su leyenda. Se ha convertido en un apóstol iluminado, en un santo laico ${ }^{28}$, un filántropo de voz paternal y suave, de sonrisa bondadosa, de ojos claros y serenos, lacrimosos por la debilidad, brillando tras unas gafas ligeramente azuladas.

Es frugal, sobrio, un asceta que no fuma, que sólo bebe agua, que jamás prueba el vino, y que come únicamente un pedazo de pan y otro de queso dos veces al día. «Había decidido que mientras millones de sus semejantes perecieran lentamente por escasez de alimentación, él no tenía derecho a más». "Conmovido ante el sufrimiento de los demás, es insensible para el dolor propio", está desprovisto de todo egoísmo. Escribe en periódicos de la Idea o traduce del inglés ${ }^{29}$ y el

27 MAURICE (1989), p. 124.

$28 \mathrm{El}$ «Cristo anarquista», le llamó Lerroux. 
resto del tiempo lo dedica a dar largos paseos de horas que le llevan a lejanos cortijos para visitar a braceros enfermos y aleccionar a los trabajadores. Todos le escuchan con un respeto casi religioso. Habla de la sociedad futura tras el triunfo de la revolución, en que no habría desigualdad ni enfermedades y prevalecería la justicia y la paz. A pesar, dice Blasco, de que era «por sí mismo incapaz de hacer daño y odiaba la violencia, la predicaba a los de abajo como único medio de salvación». Partidario de la propaganda por el hecho, había pasado gran parte de su vida en la cárcel. Son datos que corresponden a Fermín Salvochea el cual, en efecto, pasó en total 18 años encarcelado, y cuyo compromiso con el anarquismo de acción le valió una vida muy sacrificada, muy austera, siempre en la pobreza ${ }^{30}$.

Blasco insiste en una faceta de Salvatierra que conecta con el propio ideario blasquista: a pesar de su semblante mesiánico, es un ateo, tiene la certeza de que "más allá de la muerte se abría la eterna noche de la nada», y critica duramente la religión católica que hace que los parias de la tierra se resignen con el pensamiento puesto en el cielo, confiando en una compensación eterna. Critica también la caridad que es «el egoísmo disfrazado de virtud» y que no dignifica sino que envilece al hombre. En cambio, predica el derecho a la rebelión para emanciparse.

Salvatierra no participa directamente en la revuelta jerezana, aunque los campesinos acuden a la cita concentrándose a las afueras de Jerez porque se ha corrido la voz de que el viejo anarquista está en la ciudad dispuesto a dirigir el movimiento, lo cual el lector sabe que no es cierto porque las autoridades han conducido a la fuerza a Salvatierra fuera de Jerez temiendo el motín que se avecina (en la historia real, Salvochea tampoco estaba en Jerez, estaba preso en la cárcel de Cádiz) ${ }^{31}$.

En la novela no parece clara la implicación de Salvatierra, como tampoco estuvo clara en el caso de Salvochea en la historia real, a pesar de lo cual se le atri-

${ }^{29}$ En efecto, Salvochea, de familia acomodada, hijo de ricos comerciantes liberales, fue enviado a los 15 años a Inglaterra para realizar estudios comerciales y aprender inglés. Los cinco años que vivió entre Londres y Liverpool fueron decisivos en su formación intelectual y política, conectando con los círculos radicales, progresistas y socialistas, por ejemplo, con Robert Owen.

30 Muere en 1907 a los 65 años, al fracturarse la columna en una caída (de la mesa en la que dormía porque hacía días había dado su cama a un pobre). Su agonía duró tres días. Su entierro fue multitudinario, congregó a 50.000 gaditanos, una gran manifestación bajo una intensa lluvia. «Está lloviendo más que cuando enterraron al bigotes» dice una frase gaditana. «El bigotes» era Salvochea, aunque algunas coplas del Carnaval le llaman también «El barba». Sobre la figura de Salvochea, véase, Fernando de PUELLES: Fermín Salvocha. República y anarquismo. Sevilla, 1984. Pedro VALLINA: Crónica de un revolucionario. Con trazos de la vida de Fermín Salvochea. París, Solidaridad Obrera, 1958 (reed.: Cádiz, 2007).

${ }^{31}$ Aunque el dato en este caso no es histórico, bien habría podido suceder así ya que, en el pasado, en otras situaciones que se adivinaban conflictivas, Salvochea había sido detenido preventivamente y puesto en libertad poco después, por ejemplo, en vísperas de la celebración del Primero de Mayo en 1891 , con lo que se abortó la manifestación prevista. Las autoridades temían una repetición de los disturbios de 1890 con motivo de la proclamación del Primero de Mayo en homenaje a los mártires de Chicago ejecutados en 1887 (en Cádiz y Sevilla miles de obreros desfilaron por las calles para conmemorar esa fecha). 
buyó su instigación (porque se creyó probado que varios de los implicados le habían ido a ver a la cárcel para comunicarle sus propósitos de rebelión) y se le condenó a doce años de reclusión ${ }^{32}$.

En los años setenta, los historiadores franceses Gerard Brey y Roland Forgues hicieron un estudio para tratar de dilucidar lo que en el relato de Blasco lbáñez era estrictamente histórico de lo que pertenecía al terreno de la ficción ${ }^{33}$. El problema al que se enfrentaron fue la dificultad de acceso a fuentes históricas. De hecho, reconocieron no haber tenido acceso a fuentes documentales, ni militares, ni policiales ni judiciales; sólo habían podido basarse en fuentes hemerográficas, las cuales también habían resultado ser muy fragmentarias. Muy recientemente, el historiador Juan Avilés ha podido consultar los voluminosos legajos de la instrucción de la causa que se encuentran en el Archivo General Militar de Segovia, fuente crucial para poder precisar los hechos. Avilés se muestra, como el propio Blas$\mathrm{co}$, básicamente partidario de la interpretación milenarista ${ }^{34}$ : la mayoría de los amotinados, señala, estaban convencidos de que la liberación del yugo burgués estaba muy próxima y que bastaba con ponerse en marcha para que llegase ese gran día. No obstante, cree haber podido demostrar que el movimiento estaba bastante mejor preparado y organizado de lo que asegura Blasco que, en cambio, insinúa que hubo una provocación, que los campesinos fueron impulsados a una acción disparatada para poder lanzar a continuación una dura represión. Avilés cree que había unos promotores, unos líderes, los cuales eran de verdad anarquistas, que estimaban que, aunque la insurrección fracasase, la intentona sería útil por su impacto propagandístico, sería un acto de «propaganda por el hecho». En efecto, los anarquistas condenados a la pena capital por aquellos hechos parecieron tener el consuelo, por lo que dijo uno de ellos en el patíbulo, de que sus compañeros les recordasen como "los mártires de Jerez», lo que significaba que vendrían otros, después de ellos, dispuestos también a sacrificar sus vidas para vengar sus muertes.

Lo que en la novela ocurre en Jerez, una vez que los amotinados entran en la ciudad, es también bastante fiel a los hechos históricos. Las autoridades están avisadas y hay tropas esperándoles. Pero, durante unas horas, las primeras se encierran en el ayuntamiento y las segundas permanecen acuarteladas, de modo que los anarquistas se apoderan de las calles. Los moradores de la ciudad se recluyen en sus casas, o en los casinos, y los asaltantes no osan traspasar ninguna cancela

${ }^{32}$ De los que cumplió más de la mitad en los presidios de Valladolid y Burgos en condiciones penosas, antes de ser amnistiado en abril de 1899.

${ }^{33}$ G. BREY y R. FORGUES: «Algunas rebeliones campesinas en la literatura española: Mano Negra, Jerez, Casas Viejas y Yeste», en J. L. GARCÍA DELGADO (Ed.), La cuestión agraria en la España contemporánea. Madrid, Edicusa, 1976, pp.329-361. R. FORGUES: «El universo narrativo de las novelas sociales de Vicente Blasco Ibáñez», Letras de Deusto, Bilbao, vol. 8, núm. 15, enero-junio de 1978, pp. 67137. Del mismo autor: Vicente Blasco Ibáñez, mito y realidad. Barcelona, Puvill, 1987.

${ }^{34}$ Juan AVILÉS: «Milenarismo y propaganda por el hecho: la marcha anarquista sobre Jerez de 1892», en J. AVILÉS (cord.): Historia, política y cultura. Homenaje a Javier Tusell. Madrid, UNED, 2009. 
ni romper ningún cristal. No se producen saqueos ni atentados contra la propiedad. Se encuentran con una ciudad solitaria, casi vacía ${ }^{35}$. Hay un deseo de venganza, de desquite. Van en busca del «burgués». En la novela, a los pocos transeúntes que se encuentran en la calle, los rudos y feroces hombres del campo les piden que se identifiquen enseñándoles las manos. Exigirles que mostrasen las manos, dice Blasco, era «el mejor medio de reconocer a los enemigos del pobre», porque las de los ricos no tienen callos, ni las palmas llenas de durezas, ni las uñas roídas por el trabajo. Al final encuentran a un adolescente pálido, un oficinista, un escribiente, al que asesinan a sangre fría destrozándole el cráneo con una podadera. Matan a un desconocido, al primer burgués que se cruza por delante. En realidad, sabemos que fueron dos los asesinatos cometidos por los rebeldes, pero sin duda éste que se describe en la novela, el del joven escribiente, hermano menor de un concejal, fue el más brutal y del que se pudo identificar a los culpables. Le atacaron, más que por sus manos inmaculadas, como nos cuenta Blasco, porque llevaba guantes. Pero en realidad, es lo mismo: sus manos delatan su condición burguesa.

A las pocas horas, todo había terminado. El motín había fracasado. Los anarquistas fueron dispersados. Para Blasco, la rebelión de estos campesinos analfabetos no les trae más que desgracias y peor situación a la de antes. El asalto de Jerez no es sino una nueva frustración de ese círculo vicioso en el que la pasividad y la explosión de cólera se retroalimentan ${ }^{36}$. La actitud de Blasco con respecto a la violencia se parece mucho a la de Baroja, al que enseguida nos referiremos: cree que no mejora nada. El motín jerezano, como los atentados de Barcelona, sirve a las autoridades para redoblar la represión. En efecto, las autoridades y la prensa calificaron los sucesos de revolución, sublevación o insurrección ${ }^{37}$ para justificar a continuación la represión. Hubo un consejo de guerra y cuatro condenas a garrote, numerosos condenados a cadena perpetua o a muchos años de presidio, detenciones, clausura de centros obreros, suspensión de periódicos, etc., todo lo cual acalló la protesta y sumió durante unos años al anarquismo andaluz en una aguda crisis. Blasco Ibáñez cree en la posibilidad de un cambio revolucionario pero aplazado «sine die», para un lejano futuro en que la masa obrera esté suficientemente educada para emanciparse ${ }^{38}$. En este sentido, desde la ideología anarquista o re-

35 «En ningún momento mostraron la intención de robar o incendiar, lo cual resulta extraño e inhabitual en este tipo de motín». Véase MAURICE (1989, p. 123.

36 Ramiro REIG: (2002), p. 99.

37 La interpretación de que se trató de una insurrección fue recogida por la historiadora norteamericana Temma Kaplan, pero ha sido desmentida, en cambio, por otros historiadores que prefieren hablar de manifestación o asalto sobre Jerez con un objetivo preciso, la liberación de los presos de la cárcel, y no con una intención de derribar el orden social, ya que no realizaron agresiones contra la propiedad privada, ni contra las bodegas, las fábricas, etc. Véase Gerard BREY: «Crisis económica, anarquismo y sucesos de Jerez (1886-1892)», en AA.VV.: Seis estudios sobre el proletariado andaluz (1868-1939). Ayuntamiento de Córdoba, 1984, pp. 75-127. Del mismo autor: «Los sucesos trágicos de Jerez de la Frontera de 1892: un balance historiográfico», Revista de Jerez, n. ${ }^{\circ} 4$ (1998), pp. 69-76. Juan Avilés en su reciente estudio analiza pormenorizadamente la preparación del movimiento y retoma la interpretación de la insurrección.

38 Hans-Jörg NEUSCHÄFER (1995), op.cit. 
volucionaria, a Blasco algunos autores le han reprochado, lo mismo que a Baroja, que no deja de ser un burgués, o pequeño-burgués. Desde luego, ni un escritor ni otro tenían confianza en ese sueño de la «aurora roja» en que creían los anarquistas.

Blasco, como Baroja, parece creer que por el momento la única acción emancipadora puede darse en el plano particular, no en el social. Sólo individualmente es posible escaparse, como lo hacen al final de la novela Fermín y su familia. La hermana de Fermín, Mari Luz, la mujer deshonrada, queda convertida en una mujer nueva en los brazos de su novio, que es capaz de tirar por la borda los prejuicios del machismo tradicional y con ello también las secuelas del drama de honor ${ }^{39}$. Huirán, eso sí, fuera de España, para tratar de realizar en la Argentina, en un mundo nuevo, todos sus sueños.

\section{PÍO BAROJA Y AURORA ROJA}

Don Pío sentía poca simpatía hacia Blasco ${ }^{40}$ pero ambos escritores tienen mucho en común. Para empezar, los dos fueron hombres de su tiempo que escribieron sobre acontecimientos que les tocó vivir y, en concreto, se refirieron con frecuencia en sus obras al terrorismo anarquista. Como Blasco lbáñez, Baroja es un agudo observador del mundo en el que vive. Procuró conocer de primera mano los ambientes que describía. En 1896, Baroja, que había estudiado medicina pero que no tenía la más mínima vocación, decidió abandonar su puesto de médico rural para probar suerte en Madrid dirigiendo la panadería de una tía de su madre que acababa de enviudar. No tendrá éxito en este negocio familiar pero, durante esos años al frente de la panadería, tuvo abundantes contactos con las gentes de los suburbios, conoció muy de cerca una realidad socio-económica que le proporcionó abundante material literario. Baroja fue, además, un ávido lector de diarios. Pone en boca de sus personajes las polémicas que está leyendo en la prensa de la época ${ }^{41}$. La gran mayoría de los argumentos, los sucesos, los elementos sociales y los ambientes físicos que describe Baroja - las condiciones de trabajo en los suburbios, las instituciones de caridad, los ambientes marginales, los mendigos, los crímenes, etc. - se hallan ampliamente comentados en los periódicos de la capital ${ }^{42}$.

39 Ibídem, p. 302.

40 En noviembre de 1905, pocos meses después de aparecida, en febrero, La Bodega, vio la luz La horda, novela que Blasco escribió a toda velocidad, lo cual se nota. En ella hace un retrato de los suburbios y la marginación en Madrid, un submundo compuesto de vagabundos, desesperados, infelices a los que la urbe expulsa de su seno. Pío Baroja la juzgó ramplona y acusó a Blasco de haber utilizado material de su trilogía La lucha por la vida y parece que llevaba algo de razón. Véase REIG (2002), op. cit.

41 Véase Ignacio ELIZALDE: Personajes y temas barojianos. Universidad de Deusto, 1975.

42 Véase el interesante trabajo de Soledad PUÉRTOLAS: El Madrid de «La lucha por la vida». Madrid, Helios, 1971. 
Para un historiador, la trilogía La lucha por la vida, una de sus obras más famosas $^{43}$, resulta tan interesante como La Bodega porque Baroja, al igual que Blasco, recrea de forma fiel una época, la del tránsito del siglo $\mathrm{XIX}$ al $X X^{44}$. El protagonista de la trilogía es Manuel Alcázar, un inmigrante del campo que llega a la ciudad, uno más de aquella gran oleada inmigratoria de los últimos años del siglo XIX que abandonó el medio rural y comenzó a afluir a las ciudades en busca de mejor fortuna. Madrid, en efecto, estaba entonces en un proceso de asombroso crecimiento demográfico, pero la industria madrileña era incapaz de absorber y sostener esa explosión de nuevos inmigrantes ${ }^{45}$. En el peregrinaje de Manuel desde su llegada a Madrid hacia 1888, siendo un adolescente, hasta 1902, conoce múltiples ambientes y gentes que conforman un abigarrado mosaico de personajes y situaciones que nos ilustran sobre la lucha por la vida en el Madrid finisecular. La trilogía abarca catorce años en total, los que transcurren desde los trece años de Manuel hasta que se hace un hombre, su proceso de formación y de toma de conciencia sobre la realidad social en la que vive ${ }^{46}$. El mundo de los suburbios, del hampa y la mendicidad de La busca, y luego el ambiente de los artesanos de

43 Es quizás su obra más conocida y leída. Su título procedente de la teoría de Darwin, la «struggle for life» en El origen de las especies. La trilogía es un conjunto, aunque cada una de las novelas es autónoma y se puede leer y entender independientemente una de otra. Es un gran fresco colectivo, una radiografía del Madrid suburbial. Describe los arrabales, las callejuelas, los figones, los bajos fondos, un mundo de vagabundos y bribones, plagado de expresiones plebeyas y frases recias. Vemos desfilar a una abigarrada fauna callejera de mendigos, golfos, parias, rateros, ladrones, prostitutas... Parece una novela picaresca. Una amplísima galería de tipos humanos sacados de la observación directa o producto de una amplia documentación, lo que los hace muy reales. Los múltiples personajes, que a veces aparecen sólo fugazmente, ayudan a producir la sensación de un mundo hormigueante y bullicioso.

${ }^{44}$ La España que retrata Baroja es un país brutal y sin rumbo, un país repleto de miseria e injusticia, donde impera el caciquismo, la ciencia está retrasada y el panorama social y político es deprimente. España está retratada como un fracaso. Véase Roberto RUIZ DE HUYDOBRO.

45 E. INMAN FOX: «Pío Baroja. Hacia un estudio dialéctico de novela y realidad», en Jesús María LASAGABASTER (Ed.), Pío Baroja. Actas de las III Jornadas Internacionales de Literatura. San Sebastián, 1989 , p. 36.

46 La línea conductora, que proporciona cohesión y unidad al conjunto, es el proceso de formación de Manuel. En la primera novela, La busca, Manuel llega a Madrid desde el pueblo, acogido en la pensión donde trabaja su madre, la Petra. En la ciudad, Manuel se convierte en un marginado. En realidad, ni siquiera penetra en el interior de la gran ciudad. Se queda a las afueras, en el arrabal, aquella tierra «árida y negra, constituida por detritus de la civilización", los vertederos donde viven personajes que son también residuos desechados de la vida urbana. Manuel se siente identificado con el basurero de estos barrios periféricos puesto que él es también detritus de la vida urbana. Es ahí donde proliferan las chabolas, donde se hacina la masa paupérrima «convenientemente escondida de la burguesía para no ofenderla con el espectáculo de su pobreza» (véase Lily LITVAK: Transformación industrial y literatura en España (1895-1905). Madrid, Taurus, 1980, p. 94).

Vemos después evolucionar a Manuel, salir de los suburbios hacia el centro de la ciudad y vagar entre la clandestinidad, la delincuencia y el trabajo honrado. La segunda novela de la serie, Mala hierba, se sitúa en gran parte en los barrios pobres de Madrid, pero son ya barrios urbanos. La última de las novelas, Aurora roja, termina en el mismo corazón de la ciudad. Así que, a lo largo de la trilogía, en la lucha social de Manuel, se produce una ascensión geográfica (desde las afueras meridionales de Madrid al centro), y social (desde las gentes marginadas y marginales hasta el mundo obrero del trabajo). En efecto, el grado de conciencia social y politización de los personajes aumenta conforme se va penetrando en la ciudad. Mientras los personajes del principio son pasivos, apolíticos, marginados, lumpen sin proyectos ni deseos de reivindicación social, que sólo encuentran alivio a su desdichada existencia emborrachándose en las tabernas, en la última novela Baroja nos muestra ya a unos obreros plenamente politizados. 
los barrios pobres de Mala hierba dejan paso, por fin, en una gradación paralela al ascenso social de Manuel, al ámbito plenamente urbano de los obreros asalariados y de los núcleos anarquistas de Aurora Roja. En la última entrega de la trilogía se nos muestra ya un ambiente obrero politizado y con un considerable grado de agitación social.

El sueño anarquista hace su aparición en Mala hierba, la segunda novela, a través del personaje de Jesús, cajista en una imprenta, que le confía a Manuel que se ha hecho libertario. Pero es en Aurora roja donde el anarquismo alcanza absoluto protagonismo. De hecho, es una novela política en la que quedan expuestos todos los principios del movimiento anarquista español. En la taberna «La Aurora», en el madrileño barrio de Chamberí, se discuten las distintas teorías políticas del movimiento obrero. Hay en esta novela mucho diálogo, opiniones, réplicas y contrarreplicas, se exponen muchas ideas, entre otras la polémica entre el socialismo y el anarquismo. Narra Baroja la constitución de un grupo anarquista, "Aurora Roja», los debates entre sus miembros, sus distintas sensibilidades; se recrea un mitin que celebran en un teatro, e incluso un proyecto de atentado. Baroja nos muestra todo el amplio abanico de tendencias anarquistas y anarquizantes, que conoce bien ${ }^{47}$. Los personajes que aparecen son muy parecidos a los tipos reales que Baroja conoció entregados a la propagación de las ideas ácratas ${ }^{48}$.

Juan es el nuevo personaje que Baroja introduce en esta última novela de la trilogía. Es el hermano menor de Manuel. Juan abandona el seminario y sus estudios eclesiásticos, llega a Madrid para ser escultor y se convierte al anarquismo predicando una fraternidad universal casi mística. Juan representa el anarquismo idealista, altruista, humanitario y artístico, una religión que preconiza una nueva moral individual y social basada en el amor, la libertad, la bondad y la supresión del principio de autoridad. Juan da rienda suelta a sus sueños en líricos discursos en los que describe su utópica sociedad ideal.

Pero, en el grupo anarquista, cada uno tiene su propia manera de ver la Anarquía. Frente al anarquismo idealista y sensible de Juan, El Libertario -que firma con ese pseudónimo en el periódico en el que escribe - representa un anarquismo intelectual, filosófico, especulativo, menos sentimental. Es un anarquista de ideas, culto, gran conocedor de los anarquistas históricos. Él y otros anarquistas del grupo cuentan muchas anécdotas y episodios de anarquistas célebres, en concreto de los terroristas de la propaganda por el hecho que habían llevado a cabo atentados: Pallás, Salvador, Angiolillo... De Pallás se destaca su gran valentía ante la

47 Véase Ana GÓMEZ-PÉREZ (2006): «Baroja y el anarquismo: política y estética de oposición», Revista canadiense de estudios hispánicos, n. ${ }^{\circ} 30,2$, pp. 311-327.

48 Baroja asistió a muchos mítines anarquistas, probablemente en el mismo teatro Barbieri que en la novela es donde el personaje central, Juan, da un mitin. En su escrito biográfico titulado «Juventud, idolatría», del año 1917, Baroja asegura haber conocido a Reclus y a Faure en París, a Malatesta y Tarrida del Mármol en Londres, así como a varios anarquistas de acción y a dos o tres dinamiteros (p. 219, citado por Juan AVILÉS, «Pío Baroja y el anarquismo», en prensa). 
muerte. Un mes después de su ejecución, un amigo de éste hace explotar la bomba en el Liceo, el mismo día de la inauguración de la temporada. Hallamos en Aurora roja una extensa y gráfica descripción de aquella famosa detonación y la subsiguiente carnicería, contada por un anarquista que dice haber estado esa noche en el teatro. Sobre el autor del atentado, Santiago Salvador, también aparecen muchos datos, como que en la cárcel observó una conducta ejemplar, o que dio muestras de arrepentimiento y de conversión a la religión católica para evitar torturas. Los anarquistas del grupo hablan también del famoso Angiolillo, el joven anarquista italiano que asesinó a Cánovas en el balneario donde descansaba. Un hombre tímido, fino en ademanes, muy alto y delgado. También aparecen Olvés, Ruiz y Suárez, los anarquistas autores de una explosión en "La Huerta», el hotel donde vivía Cánovas. Paco Ruiz, se nos dice, murió víctima de su propia bomba porque la recogió al ver que entraba en la casa una criada con los niños y le estalló en las manos. También se alude a los anarquistas de otros países, como los mártires de Chicago o los terroristas franceses Vaillant, Henry y Ravachol.

En el grupo de Aurora Roja también hay anarquistas que están a favor de la violencia y la propaganda por el hecho, como el señor Canuto, que es el que defiende las tesis más brutales, o el Madrileño, partidario de la tendencia ilegalista que justificaba robos, atracos y otros delitos como falsificación de moneda, extorsión, etc. Los hay que practican el anarquismo destructivo y violento, que Baroja denomina "del arroyo», muy próximo a la delincuencia común, algunos que roban el oro y la plata de las sepulturas en los cementerios, a la manera del mítico Ravachol, profanador de tumbas, convertido en héroe del panteón anarquista a raíz de ser guillotinado. Ravachol, «el asaltatumbas», es uno de los anarquistas históricos más citados por Baroja, y en Aurora roja se hace alusión al hecho de haber ido cantando al patíbulo.

Vemos en la novela todo el amplio espectro de ese mundo de los anarquistas. Los hay movidos por un afán de venganza, los hay de tendencia organizativa (como Maldonado), representantes del anarquismo práctico, de industria, (como Prats, el catalán), y los hay de tendencia individualista antiorganizativa. Los hay muy elementales, o más cultivados e intelectuales; los hay silenciosos y taciturnos, pero también los hay bulliciosos, de los que entablan constantes discusiones; los hay partidarios de la dinamita y las bombas, y los hay contrarios al terror ${ }^{49}$.

En Aurora roja un anarquista italiano escribe a Juan desde París y llega a Madrid con una bomba en la maleta que piensa arrojar el día de la coronación del rey Alfonso XIII. Va a dormir a casa de Juan, el cual se ve tentado por la posibilidad de cometer un atentado con explosivos. Manuel discute con Juan sobre lo monstruoso que es provocar víctimas con un terrorismo indiscriminado. Mientras duerme el

49 Los anarquistas que desfilan, no sólo en esta novela sino por muchas otras novelas de Baroja, son, en efecto, de una gran variedad, desde los más idealistas hasta los más cínicos y farsantes. Véase Ignacio ELIZALDE: «El factor ideológico en las novelas barojianas», en Jesús María LASAGABASTER (Ed.), Pío Baroja. Actas de las III Jornadas Internacionales de Literatura. San Sebastián, 1989, p. 56. 
huésped, la mujer de Manuel, que no se ha fiado de él, le registra y le quita la bomba y cuantos documentos podrían comprometer a Juan. Cuando la policía por la mañana registra la casa, no encuentra nada.

El relato de Aurora roja puede fijarse en un tiempo real concreto, transcurre durante dos años, entre una tarde de abril de 1900 en que se produce el reencuentro entre los hermanos Manuel y Juan después de muchos años de separación, y 1902, en concreto, la fecha de la coronación de Alfonso XIII, el 17 de mayo. La muerte de Juan ocurre dos días después y su entierro, y con él el final de la novela, tiene lugar el 20 de mayo. Baroja comienza a escribirla precisamente en 1900, o sea que narra acontecimientos del más estricto tiempo presente ${ }^{50}$.

Manuel, como Juan, vive un proceso de concienciación social, ve con rabia la injusticia de la sociedad, pero está siempre en el margen del movimiento ácrata mientras Juan llega a ser en él una figura de importancia. Aunque apolítico, Manuel se siente atraído por el anarquismo, pero, en contraste con Juan, acaba encarrilando y ordenando su vida, se aburguesa, llega a convertirse en propietario de una imprenta, se rodea de trabajadores honrados, se casa y acaba llevando una vida regular, estable. Los anarquistas le llamarán con desdén un «pequeño burgués». Los dos hermanos, dos caracteres contrarios, sufren procesos inversos, el fracaso en la lucha por la vida en el caso de Juan, y el éxito en el caso de Manuel. Manuel alcanza un éxito sin grandeza, mientras Juan consume su vida en la defensa estéril de un ensueño heroico. Juan es un espíritu puro y generoso, defensor de unos ideales de imposible realización en una sociedad insolidaria y egoísta. Juan es, en este sentido, el personaje quijotesco por antonomasia de la literatura barojiana. De hecho, algún autor ha establecido un paralelismo entre Juan y Manuel, y don Quijote y Sancho51.

${ }^{50}$ E. ALARCOS LLORACH: Anatomía de «La lucha por la vida». Castalia, 1982.

51 Aurora roja comienza con la decisión de Juan de abandonar el seminario, convencido de su falta de fe. Emprende entonces un camino en el que salva las dificultades a golpe de resolución de ánimo. ‘'Adelante siempre!', se dice a sí mismo. La férrea voluntad emprendedora, es, sin duda, una de las virtudes del caballero andante. La resolución de Juan, alentada por creencias anarquistas de naturaleza filantrópica, se parece mucho al deseo de enderezar el mundo del caballero manchego. Juan es una especie de caballero loco, alguien que se rige por sus propias leyes, sin preocuparse lo más mínimo de acatar las socialmente impuestas. Juan llega a Francia y se introduce en el mundillo artístico parisino. Regresa a España con el pelo largo y se presenta ante su hermano, que apenas le reconoce. Ya están juntos caballero y escudero, voluntarioso e indolente; idealista y realista; cándido y experimentado. Juan no es un incendiario, ni un dinamitero; es, fundamentalmente, un ingenuo que a todos inspira cariño. La sociedad ha de ser devastada, sí, pero a fin de favorecer a los oprimidos, de proteger a los más débiles. Esta inocencia también le acerca al caballero andante. Su muerte, rodeado de su poca familia, recuerda vagamente a la de aquél. El poco tiempo que pasa con su hermano Manuel deja una profunda huella en éste, tal como le sucede a Sancho en contacto con don Quijote. Las aventuras cambian más al escudero que al caballero, abren sus horizontes y su mente a otras realidades. Manuel, a pesar de su mirada sobria sobre la realidad, se ve arrastrado en ocasiones por la fantasía del anarquismo que exalta a su hermano. Le acompaña a los mítines, con él funda el grupo 'Aurora roja', y, al igual que Sancho hace con su señor, protege a Juan de sus excesos de idealidad, cuando éste recibe en casa a un compañero italiano que lleva una bomba escondida en la maleta. Con el contrapunto de su hermano, Manuel crece definitivamente. De la tensión entre la exaltación de Juan y su austeridad realista, resulta, como Sancho Panza, un personaje más rico. Como en Don Quijote, el escudero sobrevive al caballero, 
Baroja tiene una visión pesimista, profundamente escéptica, sobre los resultados de las teorías anarquistas. La opción vital basada en la lucha por un ideal revolucionario no es la suya. Se fiaba sólo del individuo y le costaba mucho creer en la colectividad. Su pesimismo existencial y su exaltado individualismo le llevan a rechazar las teorías de organización social como el socialismo, del que abomina, porque no soporta los dogmas, por más que sean nuevos, ni la disciplina ni la organización. Baroja no confía tampoco en el anarquismo como teoría social, sólo simpatiza con el anarquismo en su dimensión libertaria, individualista, como teoría para transformar al individuo haciéndole espiritualmente más libre ${ }^{52}$. Comparte con el anarquismo su contenido de crítica de la sociedad, la irreverencia hacia las convenciones sociales y las tradiciones, pero no «su pretendida parte constructiva»53. El anarquismo que más le llega es el sentimental y filantrópico, pero lo rechaza por inviable. Considera el sueño anarquista de Juan hermoso, pero también una mera ilusión imposible de llevarse a la práctica. Juan es generoso, pero es un inocente creyendo que los hombres acabarán saliendo de la miseria y el vicio. Como Blasco con su personaje de Salvatierra, también Baroja siente cariño hacia el personaje de Juan y lo retrata como un hombre noble, con una enorme dignidad, con una fe inmensa en el amor y la bondad humana. Es, como Salvatierra, un visionario capaz de sacrificar su bienestar y su propia vida. Pero la ilusión de Juan se topa con la cruda realidad y el final es desolador.

El fracaso de ese sueño queda perfectamente de manifiesto con la muerte de Juan, que fallece de tuberculosis, como un poeta romántico ${ }^{54}$. Cuando, al final de la novela, Manuel vuelve del entierro de Juan, la lacónica frase «había oscurecido», nos pone ante la triste realidad de que la aurora ensoñada no se veía por ninguna parte. «Te has ido al otro mundo — dice Manuel ante el cadáver de su hermanocon un hermoso sueño, con una bella ilusión. Pero ni los miserables se levantarán, ni resplandecerá un día nuevo, sino que persistirá la iniquidad por todas partes. No podrán liberarse los humildes de la miseria, ni de la fatiga, ni del trabajo constante

y, asimismo, como en la segunda parte de la novela cervantina, el segundo personaje amenaza con oscurecer al mismo protagonista. La diferencia estriba en que el personaje introducido con posterioridad es correlato del caballero, y no el escudero. Este análisis comparativo puede verse en Gonzalo MARTíN DE MARCOS: «El recurso del segundo personaje en La lucha por la vida, de Pío Baroja, a semejanza de Don Quijote», en www.imaginando.com

52 En 1902 ya había dicho con toda claridad en Escritos de juventud: «Yo digo que no soy anarquista (...) Soy un individualista rabioso, soy un rebelde». Véase Eduardo MENDOZA: Pío Baroja. Barcelona, Ediciones Omega, 2001, p. 100.

53 Pío BAROJA: «La formación psicológica de un escritor», publicado en Rapsodias (1936) y reproducido en Obras completas, 5, p. 883, citado por Juan AVILÉS: «Pío Baroja y el anarquismo», art. cit. Hay quien sostiene que Baroja no era anarquista sino anarquizante, o más bien nihilista. Sobre el interés de Baroja por el nihilismo, los nihilistas rusos y la filosofía de Nietzsche, véase Rafael NÚÑEZ FLORENCIO: «La influencia nihilista en el anarquismo español», en J. AVILÉS y A. HERRERÍN (eds.): Los orígenes del terrorismo en Occidente: anarquía, nihilismo y violencia revolucionaria. Madrid, Siglo XXI, 2007, y Juan AVILÉS, «Pío Baroja y el anarquismo», art. cit.

54 El hermano de Baroja, Darío, murió también de tuberculosis, lo que causó al escritor honda impresión. 
y aniquilador». Como señala Lily Litvak, cuando Juan muere, "sospechamos que tal vez el grupo «Aurora Roja» muere con él»55.

Frente a esa utopía irrealizable, esa «aurora» que no llega, Baroja contrapone el esfuerzo individual de Manuel, que consigue salir de la indolencia y la marginación y acaba encarrilando su vida en el mundo sensato del trabajo honrado, gracias al influjo y la labor redentora de Salvadora, de nombre emblemático, la mujer con la que se casa y que le da estabilidad. Manuel se convierte en miembro de la clase media al hacerse dueño de una imprenta ${ }^{56}$, lo cual consigue con la ayuda de un amigo que recibe una herencia inesperada. El protagonista necesita el pequeño empujón de la suerte (la imprenta se la regalan). Baroja ni siquiera confía en que la simple lógica del sistema capitalista permita que un obrero se convierta en un pequeño empresario. Manuel se instala finalmente en una vida tranquila, «sin grandes satisfacciones pero también sin grandes dolores", una vida mediocre, gris, limitada; no es una vida feliz, porque ése es un ideal inalcanzable, sino una vida que amortigua el dolor de vivir ${ }^{57}$. Es de un escepticismo desolador. La única manera de disminuir el sufrimiento inherente a la vida es disminuir la propia vida. Baroja no se plantea alcanzar la felicidad sino reducir la infelicidad ${ }^{58}$.

\section{LA FIGURA DE MATEO MORRAL EN LA LITERATURA}

Pío Baroja, como hemos dicho, solía basarse en personas y sucesos reales, así como en experiencias propias, para escribir sus novelas, de modo que no resulta extraño que buscase inspiración en uno de los atentados anarquistas que provocaron mayor conmoción en la opinión pública: el de Mateo Morral el día de la boda de Alfonso XIII y Victoria Eugenia de Battenberg, el 31 de mayo de 1906. Cuando el cortejo nupcial se dirigía por la calle Mayor hacia el Palacio Real, aclamado por la multitud, Morral arrojó desde un balcón una bomba Orsini, similar a la

55 Lily LITVAK (1975), p. 99.

56 Por cierto que Baroja estuvo muy familiarizado con el mundo de la imprenta y se relacionó con cajistas, tipógrafos y encuadernadores que trabajaban en la editorial de su cuñado, el marido de su hermana Carmen.

57 Se ha establecido un paralelismo entre Manuel y el propio Baroja que, frente a una sociedad hostil, tiende, como Manuel, al individualismo. También como Manuel, Baroja es apocado, renuncia a todo cuanto no sea sobrevivir material y espiritualmente sin sobresaltos. Su vida, como la de Manuel, es ordenada, rutinaria. Ambos comparten ciertas simpatías anarquistas pero, ambos también, acaban recluidos en casa, en un sencillo y tranquilo hogar burgués. «Más allá de su rebelión contra la injusticia, Baroja anhelaba la tranquilidad física y espiritual que le permitiera elucubrar y escribir». Véase Eduardo MENDOZA: Pío Baroja, p.103. Ramón Sender escribió que Baroja, incluso en las obras que tratan de ser revolucionarias y subversivas, como La lucha por la vida, está lleno de prejuicios y convencionalismos. "Era esclavo de las convenciones que creía combatir. Su mundo es convencional y conservador. Sus novelas son expansiones de un conformista malhumorado. Pero conformista» (Baroja y su mundo, p. 340).

58 Joan ESTRUCH TOBELLA: «El escepticismo barojiano en La lucha por la vida», en Jesús María LASAGABASTER (Ed.), Pío Baroja. Actas de las III Jornadas Internacionales de Literatura. San Sebastián, 1989, p. 119. 
del Liceo de 1893, oculta en un ramo de flores. Los reyes resultaron ilesos, pero la explosión provocó una masacre entre la multitud que vitoreaba a la pareja real: hubo veintitrés muertos y más de cien heridos ${ }^{59}$.

Se da la circunstancia de que Baroja había conocido a Morral, aunque dice que no le trató, quizá nunca habló con él. Según cuenta Ramón Gómez de la Serna, la víspera del atentado estuvo presente en la horchatería de Candelas en la calle de Alcalá donde se reunían entre otros Azorín, Valle-Inclán, Pío Baroja y el hermano de éste, el pintor Ricardo Baroja. Baroja lo describe como «un hombre oscuro y silencioso ${ }^{60}$ que «formaba parte del corro de oyentes que hace años tenían las mesas de los cafés donde charlaban los literatos». No es de extrañar que, durante sus estancias en Madrid, el anarquista catalán acudiese a las tertulias de los artistas y escritores modernistas. Era un anarquista culto, de origen burgués (su padre tenía una fábrica de hilados en Sabadell), que había recibido una esmerada educación, completada con una estancia en Alemania, y hablaba varios idiomas, por lo que era natural que se relacionase con escritores e intelectuales simpatizantes de las nuevas ideas políticas y filosóficas finiseculares ${ }^{61}$.

Tras cometer el atentado, Mateo Morral consiguió huir y se refugió en la redacción de El Motín, semanario anticlerical dirigido por el veterano republicano José Nakens, quien le facilitó la salida de Madrid. Se vistió con un mono de mecánico y llegó hasta Torrejón de Ardoz, dispuesto a coger el primer tren hacia Bar-

59 Véase Juan AVILÉS: «Contra Alfonso XIII: atentados frustrados y conspiración revolucionaria», en J. AVILÉS y A. HERRERÍN (eds.), El nacimiento del terrorismo en Occidente. Anarquía, nihilismo y violencia revolucionaria. Madrid, Siglo XXI, 2008, pp. 141-158. Un testigo de excepción, un joven estudiante de Medicina de 17 años de edad, Eugenio Mesoneros Romanos, nieto del famoso escritor, compró aquel mismo día una cámara fotográfica por 12 duros, se situó en un balcón de la calle Mayor, dispuesto a ganar la recompensa anunciada por el diario $A B C$ que pagaría 25 pesetas por las mejores fotografías de la comitiva regia. Casi agotadas las placas, quiso tomar una foto cuando pasó la carroza del Rey bajo su balcón. Y en el preciso momento que accionaba la cámara, Morral lanzaba la bomba. La foto conseguida fue impresionante. Captó las víctimas en el suelo, la multitud presa del pánico, los caballos encabritados, soldados que apuntaban sus fusiles sin saber dónde estaba el enemigo. $A B C$ pagó al joven estudiante una cantidad exorbitante para entonces, 300 pesetas y publicó al día siguiente dicha foto. Fue todo un éxito para el joven estudiante y para el periódico. Véase página web de Museo de Antropología Médico-Forense.

60 Véase prólogo de La Dama errante, 1908. En efecto, Morral era del tipo, bastante común, del anarquista introvertido, huraño y taciturno. Delgado, demacrado, muchos le creían tísico. No se divertía como los demás jóvenes. Era muy austero y apenas comía. Se alimentaba con dos cuartillos de leche diarios. Tal era el hastío que parecía sentir por las cosas del mundo que se le creía afectado de una grave enfermedad. Esta es la descripción que del regicida hace la prensa de la época, por ejemplo, El Diluvio (Barcelona, 3 de junio de 1906) o El Liberal («Boceto psicológico de Mateo Morral», ed. de Barcelona, 4 de junio de 1906). En el mismo sentido, los periódicos se refieren a su «temperamento linfático», a que era «reconcentrado de espíritu» o a que «nunca se expansionaba». Véase Jesús M. ${ }^{a}$ MONGE: «La Rosa de Llamas: Valle-Inclán y Mateo Morral en la revista Los Aliados», El Pasajero. Revista para navegantes. UAB, Departament de Filologia Espanyola, n. ${ }^{\circ}$ 23, 2007 (www.elpasajero.com).

61 Había traducido al español la obra de un médico anarquista francés defensor de ideas malthusianas como la de fomentar la «huelga de vientres» en las mujeres, para lograr que el proletariado dejase de proporcionar trabajadores, soldados y prostitutas a la burguesía y conseguir una suerte de suicidio social. Sostenía económicamente la publicación de varios semanarios anarquistas y editó a sus expensas y repartió gratis entre las obreras de Sabadell unos textos que contenían ideas y métodos abortivos y de control de la natalidad. Tenía también inquietudes artísticas y poseía conocimientos sobre pintura. Véase Jesús M. a MONGE: «La Rosa de Llamas: Valle-Inclán y Mateo Morral en la revista Los Aliados», op.cit. 
celona. Antes de dirigirse a la estación, en la venta del pueblo, mientras comía algo, su acento catalán, sus exquisitos modales -impropios de un mecánico-y unos dedos vendados de su mano derecha levantaron las sospechas de un guarda jurado, que le requirió la documentación y le rogó que lo acompañase al pueblo. En las afueras de la venta, Mateo Morral mató con un disparo al guarda. Seguidamente se suicidó con un tiro en el pecho ${ }^{62}$.

La mayoría de los escritores de aquella tertulia a la que Morral había acudido la víspera se acercaron hasta el hospital del Buen Suceso de Madrid para contemplar impresionados su cadáver. Valle-Inclán cuenta que fue en compañía del pintor Ricardo Baroja: «Mateo Morral, pasajero hacia su fin, estuvo en nuestra tertulia la última noche. Le conocimos juntos y juntos fuimos a verle muerto. Ricardo Baroja hizo entonces un bello aguafuerte. Yo guardo la primera prueba» ${ }^{63}$. «Después de cometido el atentado y encontrado a Morral muerto cerca de Torrejón de Ardoz - dice, por su parte, Pío Baroja - quise ir al hospital del Buen Suceso a ver su cadáver, pero no me dejaron pasar. En cambio, mi hermano Ricardo pasó e hizo un dibujo y luego un aguafuerte del anarquista en la cripta del Buen Suceso. Mi hermano se había acercado al médico militar que estaba de guardia a solicitar el paso, y le vio leyendo una novela mía, también de anarquistas, Aurora Roja. Hablaron los dos con este motivo, y el médico le acompañó a ver a Mateo Morral muerto» ${ }^{64}$.

Baroja dedicó a este episodio, que le había causado una honda impresión, la novela La dama errante $(1908)^{65}$, cuyos protagonistas son el médico Enrique Aracil y su única hija, María, una joven de dieciocho años. El doctor conoce al terrorista Nilo Brull, que es el nombre que tiene Mateo Morral en esta novela. Baroja, nos hace de él un retrato psicológico: «En el fondo, toda su alma estaba henchida por una vanidad monstruosa; quería llamar la atención de la gente, sorprenderla».

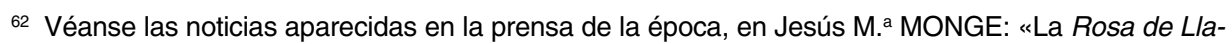
mas: Valle-Inclán y Mateo Morral en la revista Los Aliados", op. cit.

Está también el testimonio de otro novelista, muy conocido en su época, Alberto Insúa, encuadrado entre los escritores de la llamada Generación del 14: «Pasaron dos o tres días al cabo de los cuales se supo que el autor del regicidio frustrado se llamaba Mateo Morral, que había sido profesor en la escuela del revolucionario Francisco Ferrer, en Barcelona, y que después de refugiarse durante unas horas en la redacción de El Motín, el periódico anarquista de Nakens, anduvo errante por el campo hasta que, hambriento, entró en un ventorrillo de los alrededores de Torrejón de Ardoz y pidió de comer. Infundió allí sospechas y algunos de los presentes fueron a buscar al guardia jurado Francisco Vega. Interrogó éste al sospechoso y lo intimó a seguirle. Obedeció Morral, pero a corta distancia del ventorro sacó un revolver, disparó sobre Vega, matándole en el acto y después, con la propia arma, se quitó la vida. Se dijo que cierta mujer había sido la causante indirecta del crimen. Era la amiga íntima del ácrata Ferrer, de la cual se había enamorado Morral. Como ésta lo rechazara, el anarquista amenazó «con hacer una locura». Mataría a los reyes. (Años más tarde personas que trataron a Soledad Villafranca, en París, después del fusilamiento de Ferrer, me dijeron que ella insistía en esta explicación de la tragedia, que habría de constituir en cierto modo, con variantes de lugar y de tiempo, el asunto de una novela corta mía titulada La hiel. (Véase Alberto INSÚA: Memorias. Madrid, Fundación Santander Central Hispano, 2003, p. 132).

63 En el prólogo de El pedigree.

64 Prólogo de La dama errante. También Pérez de Ayala en su novela Troteras y Danzaderas recordará, a través del personaje de Santonja, el atentado de Morral y la exposición pública de su cadáver.

65 Es la primera novela de la trilogía La raza (las otras dos: La ciudad de la niebla y El árbol de la ciencia). 
A diferencia de Kaliayev, el anarquista de Los justos de Camus, éste sí se atreve a lanzar la bomba, aún cuando sabe que va a matar a mucha gente ${ }^{66}$. «En el momento terrible, cuando estaba en el balcón con la bomba en la mano, vi en la calle unas cuantas muchachas que reían. Sin embargo, no vacilé», confiesa Brull en la novela. Es lo que muy probablemente pensó Morral, que no sentía ninguna piedad hacia todas aquellas personas, que él juzgaba estúpidas y serviles, que se divertían presenciando un espectáculo para él execrable. Es sabido, en efecto, que Morral había desarrollado un gran odio hacia todo signo de ostentación y lujo social, de modo que consideró que aquella boda real, con todo su boato, era una ocasión perfecta para cometer una acción propagandística de violencia anarquista. Después de cometer el atentado sin lograr su objetivo, Brull escapa en el tumulto que se produce y busca refugio en casa del doctor Aracil, que le acogerá. Aracil es con toda claridad la contrafigura del publicista republicano José Nakens ${ }^{67}$.

Entre los numerosos detenidos (aunque sólo durante unas horas) e interrogados tras el atentado de Morral, se encontraba el escritor gallego Julio Camba ${ }^{68}$, entonces un joven anarquista de veintiún años, procesado varias veces por delitos de imprenta, asiduo asistente a las tertulias literarias y artísticas, amigo de Unamuno, los Baroja y Valle-Inclán. Nacido, como éste último, en Villanueva de Arosa (Pontevedra), con dieciséis años se escapó de casa para evitar ingresar en un seminario, como deseaban sus padres, y se escondió entre cajas en un barco de emigrantes atracado en Vigo con destino a Argentina. En Buenos Aires entró enseguida en contacto con los ambientes anarquistas. Tras escribir en la prensa anarquista, dar alguna conferencia en círculos libertarios y promover una huelga general revolucionaria, fue expulsado y enviado de vuelta a España en 1902. Julio Camba señaló con humor que era el único español a quien el viaje de ida y vuelta a América no le había costado una sola peseta. Quizá, deseoso de regresar a su país, provocó él mismo su expulsión profiriendo gritos subversivos en plena calle. Una vez en Madrid, publicó El Rebelde (1903-1905), un semanario anarquista cuya cabecera figuraba en la última página, como símbolo humorístico de inversión de todos los valores ${ }^{69}$. Su anarquismo era individualista. En realidad, según su biógrafo, era sólo un rebelde, incluso un reaccionario, aunque él todavía no lo sabía ${ }^{70}$.

En junio de 1907 tuvo lugar el proceso contra los cómplices del magnicidio (la famosa «Causa de la bomba») por el que fueron juzgados, entre otros, los intelectuales Francisco Ferrer y José Nakens. Camba no compareció en el juicio, pero sí se leyó su declaración sumarial, en la que manifestó que, siendo director de

66 Ignacio ELIZALDE, op. cit. p. 172.

67 El doctor, perseguido por la policía como cómplice, no tarda en verse obligado a huir en compañía de su hija. Los dos abandonan Madrid, camino de Portugal y, finalmente, se exilian en Inglaterra.

68 Según Pedro Ignacio LÓPEZ GARCíA, Julio Camba. El solitario del Palace, Madrid, Espasa, 2003, p. 63, Morral utilizó la credencial de Camba para asistir como periodista a la boda de Alfonso XIII y poder moverse con libertad.

69 Ibídem, p. 46.

70 Ibídem, p. 49. 
El Rebelde, había recibido en la redacción a Mateo Morral. Con motivo del proceso escribe Camba una semblanza de Morral para España Nueva: alto, delgado, bien vestido, culto, inteligente, sonriente, poco hablador. Durante seis o siete días, le sirvió de guía en Madrid; aunque no llegaron a ser amigos íntimos, pasearon y fueron juntos a cervecerías y cafés. Camba fue también al Hospital del Buen Suceso a examinar el cadáver del anarquista y reconoció a quien había sido su esporádico amigo dos años antes ${ }^{71}$.

Valle-Inclán se refiere también varias veces a Mateo Morral en su obra ${ }^{72}$. Su poema Rosa de Llamas está dedicado al ácrata terrorista ${ }^{73}$. Le impresiona su encuentro con Morral la víspera del atentado en la cervecería de la calle de Alcalá ${ }^{74}$, y le impresiona su determinación por una causa perdida de antemano. Mateo Morral a los ojos de Valle-Inclán adquiere categoría de héroe trágico que se enfrenta a un destino ya establecido. En el poema se presenta al anarquista en el momento de la huida, tras cometer el atentado, vagando por los caminos y por los campos de las afueras de Madrid, poco antes de su último homicidio y posterior suicidio, por lo que el espacio poético refleja la turbación interior del anarquista, la emoción y el misterio de la tragedia que va a suceder. El poema contiene algunas metáforas muy inteligibles: "Y el ramo de venas saltante en las sienes», que acabó estallando «en las ruedas del Carro Real».

El tema anarquista está presente en otras obras de Valle. En Baza de espadas, ambientada en la revolución de 1868, recrea literariamente a dos anarquistas históricos. En un buque, camino de Londres, hablan Bakunin y un grupo de conspiradores españoles, entre ellos Fermín Salvochea ${ }^{75}$. Por su parte, en una escena muy expresiva de Luces de Bohemia, critica duramente la ley de fugas ${ }^{76}$. Es un diálogo en el calabozo de una cárcel entre Max Estrella y un anarquista catalán, cuyo nombre es Mateo, en homenaje a Morral pero también a todos los anarquistas asesinados por la aplicación de la ley de fugas. En dicha escena el lenguaje revolucionario y el religioso van a la par, y así, por ejemplo, la revolución es califica-

71 Según López García (2003, p. 62), Camba y Morral habían sido presentados dos años antes del atentado por Pío Baroja en el Café Oriente de la Puerta del Sol, pero no parece que pueda ser así puesto que Baroja asegura que no llegó nunca a hablar con Morral.

72 Véase Leda SCHIAVO: Historia y novela en Valle-Inclán. Madrid, Castalia, 1980.

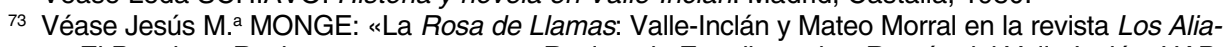
dos", en El Pasajero. Revista para navegantes. Revista de Estudios sobre Ramón del Valle-Inclán. UAB, Departament de Filologia Espanyola, n. ${ }^{\circ}$ 23, 2007 (www.elpasajero.com). La primera versión del poema se publica en 1918 en la revista Los Aliados el 20 de julio de 1918, en el número 2. Se trata de su única colaboración en la revista. No deja de ser paradójico, aunque muy propio de Valle-Inclán, que publique el poema en una publicación aliadófila defensora del modelo social capitalista contra el que luchaba ciegamente Mateo Morral. Paradoja o boutade valleinclaniana. Valle publicó otras dos versiones posteriores de este poema. La segunda versión, sólo ligeramente modificada, en 1920. La tercera versión, definitiva, se publicó en Claves líricas en 1930.

${ }_{74}$ Una coincidencia en la que cree ver una revelación del destino, con un sentido oculto: «En mi senda estabas, lóbrego lucero»; «iTú fuiste en mi vida una llamarada!». Véase, Jesús M. ${ }^{a}$ MONGE, op. cit.

75 Ricardo SIGNES ANDREU: «Historia y ficción en Baza de espadas: una aproximación a las ideas políticas del último Valle», en Insula: Revista de letras y ciencias humanas, N. ${ }^{\circ}$ 578, 1995, pp. 13-15.

76 La escena fue añadida en 1924, con posterioridad a la primera versión de 1920. 
da como «la religión nueva». El preso, un obrero anarquista, esposado, con la cara llena de sangre, habla de la situación de guerra social que se vive en Barcelona y asegura que conoce muy bien la muerte que le espera: «cuatro tiros por intento de fuga», "por siete pesetas, al cruzar por un lugar solitario, me sacarán la vida los que tienen a su cargo la defensa del pueblo". Al final de la escena, en efecto, el carcelero le llama: «Andando, gachó, que vas a ir en viaje de recreo». Se despide con resignada entereza sabiendo que van a matarle.

\section{EDUARDO MENDOZA Y LA VERDAD SOBRE EL CASO SAVOLTA}

Esta escena ocurre en los mismos años en los que Eduardo Mendoza sitúa la acción de su primera novela, La verdad sobre el caso Savolta. Los años del pistolerismo en que la violencia social y los atentados terroristas alcanzaron su clímax, en los en que el asesinato se convirtió en una táctica sistemática ${ }^{77}$. La Cataluña industrial, y muy en concreto la ciudad de Barcelona, va a ser el espacio privilegiado de este nuevo terrorismo de la pistola, el arma utilizada de manera prioritaria, empuñada, cada vez más, por pistoleros profesionales que mataban por una retribución fijada de acuerdo con la importancia de la víctima y el riesgo que entrañase el atentado.

Es la Barcelona del conflictivo periodo entre 1917 y 1919, años de guerra en Europa, en los que la empresa Savolta, fabricante de armas, ha hecho un gran negocio gracias a sus exportaciones a Francia, pero ve peligrar su imperio económico con la crisis de posguerra y contempla asustada los conflictos obreros propiciados por dicha crisis. El ambiente de la Barcelona de finales de la primera guerra mundial, que la novela consigue recrear muy bien, se caracteriza por el fuerte contraste entre el ostentoso lujo de la burguesía, que ha obtenido inmensas riquezas aprovechando la neutralidad española para abastecer a las potencias beligerantes, y la pauperización del proletariado industrial. Esta situación provocó un duro enfrentamiento entre patronos y obreros, cada vez más radicalizados en sus respectivas posiciones; los primeros, amparados por las autoridades, hacen gala de un intransigente egoísmo; los segundos, dirigidos cada vez más por anarquistas, creen por fin llegada la hora final del dominio burgués. El clima social que planea de fondo en la novela es el de la guerra social, la espiral de violencia, la intervención de matones y pistoleros a sueldo, los confidentes de la policía, los atentados de dudosa autoría, los enigmáticos espías que se hacían pasar por aristócratas... Literariamente es un tema perfecto para escribir una novela, mezcla irónica del viejo folletín y de la moderna novela policíaca ${ }^{78}$.

77 Véase Gerald H. MEAKER: La izquierda revolucionaria en España, 1914-1923. Barcelona, Ariel, 1978.

78 Véase Eduardo RUIZ TOSAUS: «El caso Savolta de Eduardo Mendoza, treinta años después», Espéculo. Revista de estudios literarios. Universidad Complutense de Madrid, 2005. Seguimos en gran parte a este autor en el análisis de esta obra. Ruiz Tosaus presentó su tesis doctoral: «La narrativa de 
Chantaje, intimidación y asesinato fueron igualmente practicados por proletarios y patronos. Mendoza recrea este fenómeno de mutua destrucción, aunque hace sobre todo responsable a la burguesía catalana. La verdad sobre el caso Savolta muestra un escenario de brutal explotación del obrero y de corrupción de la alta burguesía, y expone la confabulación entre los órganos represivos del Estado y el gran capital. En la dinámica de la lucha de clases, la clase dominante se acaba imponiendo ${ }^{79}$.

Publicada en 1975, tres meses antes de la muerte de Franco ${ }^{80}$, La verdad sobre el caso Savolta, a pesar de ser obra de un autor novel, marcó un punto de inflexión en la novela española. Mendoza no escribe, al contrario que Baroja, Blasco o ValleInclán, sobre la experiencia vivida, sino sobre un periodo histórico para él muy lejano en el tiempo, pero del que ha llegado a saber mucho cuando comienza la escritura de su novela. De pequeño había escuchado un sinfín de historias sobre la Barcelona de aquella época en su casa, y se encontró de nuevo con el tema por su trabajo como abogado de la compañía hidroeléctrica «Barcelona Traction, Light and Power», conocida popularmente como «La Canadiense» (por ser su capital anglocanadiense), dedicada a explotar los recursos hidráulicos del río Ebro y sus afluyentes para suministrar electricidad a la ciudad condal. En febrero de 1919, en la aguda crisis social de posguerra, tras la reducción del salario a algunos de sus obreros, se desencadenó una huelga de solidaridad sin precedentes, la cual acabó derivando en una huelga general de enormes proporciones que paralizó totalmente la ciudad de Barcelona. Fue la famosa «huelga de La Canadiense», nunca igualada por su magnitud en España, la huelga más importante de la historia sindical española. Muchos años después, en 1970, la empresa fue expropiada por el gobierno español, que ganó un litigio internacional ante el Tribunal de La Haya. Eduardo Mendoza, ejerciendo de abogado por aquellos años, fue uno de los letrados encargados del caso. «Mi función allí —afirmó en una entrevista— era entrar en los archivos de la empresa, ir leyendo documentación e ir ordenando el material. Así tuve acceso a mucha documentación, aunque no excesivamente reveladora. Nun-

Eduardo Mendoza, paradigma de la transgresión (1975-1996)» en la Uned en 2001. Del mismo autor véase también: "Sobre los personajes de La verdad sobre el caso Savolta de Eduardo Mendoza», Revista Lindaraja, n. ${ }^{\circ}$, junio de 2004.

79 Esta interpretación de una burguesía catalana egoísta y provocadora es la que ofrece también Casal Gómez en el libro en el que Mendoza se basó exhaustivamente para la trama de su novela. Véase Jacques SOUBEYROUX: «De la historia al texto: génesis de La verdad sobre el caso Savolta de Eduardo Mendoza» en XI Actas de la Asociación Internacional de Hispanistas, 1992, p. 374 (se puede ver en internet en la web del Centro Virtual Cervantes).

80 Ruiz Tosaus ha creído ver un paralelismo entre aquellos apasionantes sucesos y lo que estaba ocurriendo en la España de 1975. España era, como en los años 1917-19, un estado en descomposición. No es casualidad, asegura Ruiz Tosaus, que aquel clima de crispación que narra Mendoza en su novela coincida con el vivido en torno al año 1975: atentados de ETA a partir del asesinato de Carrero Blan$\mathrm{co}$, huelgas obreras, resurgimiento de las centrales sindicales, represión social contra sindicalistas, terrorismo del FRAP, acciones violentas de los llamados guerrilleros de Cristo Rey, resurgir de bandas anarquistas en Barcelona (Salvador Puig Antich), últimas penas de muerte. Esta violencia lleva a Mendoza a plantearse gran parte del tema central de su novela: la búsqueda de las razones por las cuales la libertad en España acarrea inexorablemente la violencia. Véase Eduardo RUIZ TOSAUS (2005): «El caso Savolta de Eduardo Mendoza, treinta años después», op.cit. 
ca descubrí esa conspiración que todos buscamos, pero sí un aspecto muy interesante: la forma de ir relatando un suceso a base de mínimos detalles marginales» ${ }^{81}$.

Ante aquella minuciosa y desordenada documentación archivística, Mendoza aprendió lo que es el oficio del historiador, la reconstrucción del pasado. En la novela aparecen artículos periodísticos, fichas policiales, documentos judiciales, cartas y otros documentos de los que con frecuencia se vale el historiador para elaborar sus estudios. Algunos son reales, otros ficticios, pero el hecho es que, con esta táctica documental, Mendoza consigue dar al lector una impresión de autenticidad. No obstante, aunque es una novela histórica, se trata de una novela al fin y al cabo, de modo que, de forma voluntaria, Mendoza manipula los datos históricos mediante anacronismos, elipsis o, simplemente, invenciones, para evitar que haya una total identificación con la realidad histórica ${ }^{82}$.

Además del archivo de La Canadiense, para recrear el marco histórico, Mendoza leyó muchos libros referidos a aquella Barcelona ensangrentada del terrorismo, especialmente en el periodo comprendido entre 1918 y 1921, muchos de ellos escritos más o menos coetáneamente a los hechos narrados. En la propia novela, Mendoza cita, en una nota preliminar, una serie de obras de las que ha extraído información y que han sido analizadas por algunos autores, confrontándolas con el texto de Mendoza ${ }^{83}$. Se inspira en ellas, no sólo para captar el ambiente general de

81 Ajoblanco, noviembre 1986, p. 55.

82 Véase entrevista de Miguel Herráez a Mendoza, Debats, 56, 1998, p. 123. Véase también, Jacques MAURICE: «De la manipulation de I'Histoire dans La verdad sobre el caso Savolta» en Yvan LISSORGUES (coord.): La renovation du roman espagnol depuis 1975 (Actes du colloque des 13 et 14 février 1991). Toulouse, Presses Universitaires du Mirail. Collection Hespérides, 1991, pp. 75-85.

${ }_{83}$ Varios autores han analizado de forma pormenorizada los elementos que Mendoza ha tomado de cada uno de esos libros. Véase Jacques SOUBEYROUX: «De la historia al texto: génesis de La verdad sobre el caso Savolta de Eduardo Mendoza» en XI Actas de la Asociación Internacional de Hispanistas, 1992 (se puede ver en internet en la web del Centro Virtual Cervantes). Véase también, Eduardo RUIZ TOSAUS: «El caso Savolta, entre realidad y ficción», Espéculo. Revista de estudios literarios. Departamento de Filología 3. Universidad Complutense de Madrid, núm. 18, julio-octubre 2001. Del mismo autor: «De la transgresión histórica en La verdad sobre el caso Savolta de Eduardo Mendoza» en David Knutson and Jeffrey Oxford (Eds.): Eduardo Mendoza. A new look. New York, Peter Lang Ed. (Currents in comparative romance languages and literatures) Vol. 112, 2002, pp. 147-158. «Sobre algunas fuentes narrativas en la obra de Eduardo Mendoza», HiperFeira. International Journal of Arts and Literary Criticism, State University of New York at Stony Brook, abril 2002.

Entre los cinco libros que relatan aquellos hechos y que Mendoza cita como fuente de su obra, destacan dos de ellos, de los que se ha valido especialmente el autor de la novela: Manuel CASAL GÓMEZ: Origen y actuación de los pistoleros. Barcelona, Publicaciones Mundial, 1977 (prohibido en la dictadura de Primo de Rivera, se publicó bajo la Segunda República y fue reeditado en 1977). Se trata de una narración escrita por un ex Comisario de Policía de Barcelona, inspector jefe de la brigada de investigación criminal, que revela hechos que conoció, como él mismo afirma, por razón de su cargo. El libro es un repaso a la actuación de los pistoleros anti-sindicalistas durante el periodo 1918-1921; nos habla de personajes como Bravo Portillo, el Barón de Koenig, Milans del Bosch, Arlegui, Martínez Anido, la Patronal y los Sindicatos Libres. El segundo libro es el de Pere FOIX: Los archivos del terrorismo blanco. El fichero Lasarte. Barcelona, Ariel, 1931. Su autor, un periodista anarquista, sindicalista de la C.N.T, que debió esconderse y exiliarse ante el acoso policial, se refiere a este fichero policial para repasar las turbias técnicas empleadas por las fuerzas del orden contra los movimientos de izquierda, como la famosa ley de fugas. El «fichero Lasarte» es una estadística de sucesos de carácter social ocurridos entre 1910 y 1928 , donde se reunían pruebas, documentos y fotografías de supuestos anarquistas de la época y fue confeccionado por dos comandantes y un capitán, Julio Lasarte, de ahí su nombre. 
la época, sino para crear a muchos de sus personajes, incluso para atribuirles nombres propios, y también para la propia estructura narrativa, por ejemplo, incluyendo documentos o fichas policiales, como ocurre en algunos de esos libros ${ }^{84}$.

Además de sus largas horas de lectura en bibliotecas ${ }^{85}$, Mendoza leyó profusamente la prensa de la época. Pasó más tiempo en la hemeroteca documentándose que luego escribiendo la novela. Quería impregnarse del carácter de la época para escribir un relato histórico muy alejado de lo que en aquel momento era la Historia académica, una historia fundamentalmente social y económica, con muchas tablas de precios, análisis estadísticos, fluctuaciones de la moneda y otros datos científicos. Mendoza quería contar una historia más humana, describir un escenario de personajes que andan por la calle, que están vivos.

Así que Mendoza se documentó mucho y luego combinó todo ese material, artículos de periódico, documentos judiciales, cartas, recuerdos..., a través de los cuales el lector accede a las visiones que sobre los hechos tienen los distintos personajes; esa multiplicidad de puntos de vista favorece la explicación polivalente de la realidad ${ }^{86}$.

Aparecen, se cita o se alude a personajes históricos relevantes, políticos como Francesc Cambó, Alejandro Lerroux, Antonio Maura, García Prieto, Eduardo Dato y otros como Cánovas, Sagasta, el ingeniero Pearson de La Canadiense, e incluso Alfonso XIII ${ }^{87}$. También se cita a conocidos anarquistas revolucionarios como

${ }^{84}$ Eduardo RUIZ TOSAUS: «El caso Savolta, entre realidad y ficción» (2001). Aparte de las obras citadas por el propio Mendoza, Ruiz Tosaus se refiere a una novela de Francisco BASTOS ANSART, Pistolerismo (Historia trágica) publicada por Espasa-Calpe en 1935, que no sólo posee muchos de los personajes de La verdad, sino también la misma situación espacio-temporal, el mismo núcleo temático central, e incluso un final similar. Ruiz Tosaus señala que los puntos de conexión entre la novela de Bastos Ansart y la de Mendoza son tantos, que es imposible que Mendoza no la hubiera conocido. Entre los personajes similares está la Lucerito, que tanto se parece a la María Coral de la novela de Mendoza, una gitanilla artista de cabaret de los bajos fondos barceloneses que, consciente de la seducción de su beIleza misteriosa, la utiliza para salir de la miseria al coste que sea.

${ }_{85}$ A través de las múltiples fuentes consultadas, Mendoza logra impregnarse también del lenguaje de la época. Hay en la novela una amplia variedad de registros lingüísticos, en no pocas ocasiones con una intención irónica o paródica. Las diferencias sociales de los distintos personajes quedan patentes en ese abanico léxico. Según el origen social de cada uno, Mendoza utiliza distintos estilos, desde el más formal, correcto y culto, incluso elegante, o de una empalagosa pedantería en el caso de los burgueses adinerados, hasta el coloquial, vulgar e incorrecto, e incluso la jerga barriobajera y malsonante del submundo del cabaret y las tabernas. Mendoza recrea también lenguajes específicos, profesionales o científicos. Hay un lenguaje jurídico y administrativo en un minucioso y tenaz interrogatorio judicial. Pajarito de Soto, por su parte, habla y escribe como hablaban los periodistas anarquistas, en un tono de discurso político y mitin propagandístico. Hay, en definitiva, muchos tipos de lenguajes: el jurídico, el político, el administrativo, el sentimental, el periodístico, etc.

${ }^{86}$ Mendoza va entregando al lector fragmentos o piezas sueltas que poco a poco van encajando y que permitirán, al final de su lectura, la visión completa del complicado rompecabezas, al estilo de la estructura de la novela policíaca: de la confusión hacia la claridad final. La obra se plantea como una «novela enigma», una novela de intriga, de suspense, con múltiples puntos que permanecen oscuros durante el desarrollo de la acción. Ese montaje de secuencias hace que la novela resulte también muy cinematográfica. Véanse a este respecto los artículos de Eduardo Ruiz Tosaus citados.

87 En alguna ocasión, entre los ilustres invitados a las magníficas fiestas de los Savolta, están los mismos Reyes de España. 
Paulino Pallás, Santiago Salvador, Ramón Sempau, Salvador Seguí y Francisco Ferrer Guardia, así como otros de quien novelescamente se sospecha que tienen relación con «el caso Savolta» como Andrés Nin.

Por lo demás, varios de los personajes centrales de la novela están inspirados en personajes reales. El industrial Savolta está basado en la figura histórica del empresario metalúrgico José Alberto Barret, cuya fábrica, situada en la carretera del puerto, como en la novela, producía espoletas de obuses para equipar al ejército francés durante la Primera Guerra Mundial. Barret fue asesinado el 8 de enero de 1918 (una semana después que el Savolta de la novela ${ }^{88}$ ) cerca de la Escuela Industrial, de la que era profesor (no en su casa, como en la novela) ${ }^{89}$. Su muerte causó una honda impresión en Cataluña. Barret tenía fama de ser extremadamente duro, de defender las posturas más intransigentes frente a las huelgas, coaccionando a otros patronos para que no accedieran a las demandas de los trabajadores, de ahí que la primera reacción del órgano de la CNT fuese asegurar que «a cada puerco le llega su San Martín»" ${ }^{90}$. Las autoridades atribuyeron el atentado a los grupos de acción anarquistas. El dirigente sindicalista Ángel Pestaña, sin embargo, aportó numerosos datos destinados a probar que fue el servicio de espionaje alemán, a cuyas órdenes estaba el comisario de policía Bravo PortiIlo, quien ordenó a éste matar al empresario ${ }^{91}$. Esta misma tesis fue sostenida por otros autores, en cuyas obras se documentó Mendoza ${ }^{92}$. En efecto, parece históricamente comprobado que el gobierno alemán financió una guerra sucia, manipulando a grupos de acción anarcosindicalistas a los que utilizó para amenazar, agredir e incluso eliminar a patronos aliadófilos. De hecho, algunos autores sitúan en esta turbia historia de espionaje el inicio del terrorismo social en Barcelona.

En esa Barcelona convertida en teatro de operaciones del espionaje de las potencias beligerantes, hace acto de presencia un personaje de existencia real,

88 Véase SOUBEYROUX (1992), pp. 371-372.

89 «Caminaba tranquilamente en compañía de un colega cuando «sonaron unos cincuenta disparos de revólver» (Solidaridad Obrera, 10 de enero de 1918). El señor Barret cayó mortalmente herido, pues recibió doce heridas por arma de fuego, seis de ellas con orificio de entrada y salida. «Los agresores, favorecidos por la falta de luz y lo solitario de aquel barrio, diéronse precipitadamente a la fuga, sin que pudiese ser detenido ninguno de ellos» (El Diluvio, Barcelona, 9 de enero de 1918, citado por Eduardo Ruiz Tosaus).

90 Solidaridad Obrera, 9 de enero de 1918.

91 Previamente Bravo Portillo, valiéndose de un obrero de la fábrica que era confidente de la policía, había intentado plantear un conflicto laboral incitando a los obreros a la huelga para interrumpir la fabricación de armamento con destino a los aliados. Véase Ángel PESTAÑA (1933): Lo que aprendí en la vida, Madrid, Ed. Aguilar, pp. 171-174. Pestaña logró también demostrar que Solidaridad Obrera, el diario de la organización sindical, cobraba de la Embajada alemana, lo que causó que cesase en su cargo el director de la publicación y Pestaña fuese nombrado en su lugar. En su obra Terrorismo en Barcelona (pp. 88 y ss.), Pestaña relata pormenorizadamente el juicio por el asesinato de Barret donde quedaba clara la existencia del confidente, Eduard Ferrer, presidente del Sindicato Metalúrgico, que fue procesado junto a cinco integrantes de este sindicato. Ninguno fue detenido ni encarcelado. Según Pestaña, los asesinos se embolsaron 15.000 pesetas pagadas por la Embajada alemana.

92 Pere FOIX: Los archivos del terrorismo blanco y Francisco de P. CALDERÓN e Isaac ROMERO: Memorias de un terrorista. Novela episódica de la tragedia barcelonesa, Barcelona, 1917. 
aunque más parece de ficción, por lo que no es en absoluto extraño que Mendoza se lo apropiase para construir a uno de los personajes centrales de la novela. Se trata del falso barón de Koenig, un aventurero alemán, vividor, farsante, estafador, que fingió ser, en los muy diversos países en los que residió, un personaje de alcurnia, utilizando siempre nombres falsos. En 1918 se instaló en Barcelona con su mujer y su amante, y ofreció sus servicios a la Federación Patronal, prometiendo acabar con el desorden social ${ }^{93}$. La banda del barón de Koenig introdujo en Barcelona el veneno del «terrorismo blanco». Este personaje real está encarnado en la novela en el personaje de Paul André Lepprince ${ }^{94}$, joven extranjero, en este caso un francés de madre española ${ }^{95}$, síntesis perfecta de dandy y rufián, que nada más llegar a Barcelona fascina a todos, empezando por Savolta, que le contrata, y encandila asimismo a la hija de éste. Su nombre es alusivo a su personalidad, es en francés «el príncipe». Elegante, apuesto, arrogante, seductor, deslumbra por sus dotes persuasivas y sus distinguidas maneras. Envuelto en un aire de misterio, Lepprince es un trepador amoral, ambicioso e intrigante. Ante la amenaza de huelga en la fábrica Savolta, decide contratar a dos matones para que den un escarmiento a sus cabecillas. Éstos son apaleados y la huelga fracasa. Nada le detiene, recurre fríamente al crimen. Guapo, refinado, brutal, se acaba casando con la hija de Savolta, rica heredera, tras haber hecho matar al que iba a ser su suegro. La fascinación que ejerce en todos los que le conocen le facilita su tarea.

Acabaremos sabiendo que Lepprince, no sólo ha mandado asesinar a Savolta sino que es también responsable de otras muertes, como la de uno de los directivos de la empresa que, al descubrir las secretas maniobras de Lepprince, es asesinado por los esbirros de éste. Lo mismo le ocurre al periodista Domingo Pajarito de Soto, que descubre que la empresa Savolta ha suministrado clandestinamente armas al ejército alemán, denuncia los hechos en un periódico anarquista $^{96}$, y acaba muriendo en extrañas circunstancias. Pajarito es un periodista marginal, desvalido, idealista e ingenuo, comprometido con su ideología utópica y con la causa de la lucha obrera que absorbe toda su atención y le mantiene paradójicamente insensible y ciego ante la miseria y el desamparo de su propia familia,

93 Las andanzas reales de este personaje fueron relatadas por el comisario Casal Gómez en uno de los libros que cita el autor al inicio de la novela como fuente bibliográfica: La banda negra. El origen y la actuación de los pistoleros en Barcelona (1918-1921). Véase también, VENTURA SUBIRATS, Jorge (1971): «La verdadera personalidad del barón de König», Cuadernos de Historia Económica de Cataluña, a.V, Barcelona, pp. 103-118.

94 Según SOUBEYROUX (1992, p. 374), Mendoza ha extraído del libro de Casal Gómez el retrato que éste hace del barón de Koënig, trasladándolo de forma casi exacta a la novela para su descripción de Lepprince. prince.

${ }^{95}$ La figura de Max, su guardaespaldas, este sí, espía alemán, es un desdoblamiento del propio Lep-

96 El artículo de Pajarito de Soto en que relata el atentado contra un obrero reproduce literalmente el relato de Casal Gómez sobre el asesinato del obrero tintorero Pablo Sabater, «el Tero» por parte del agente alemán y responsable del terrorismo blanco, Bravo Portillo. Soubeyroux dice que hay frases enteras, de una gran carga dramática y emotiva, del texto de Casal que Mendoza traslada directamente a la novela y afirma que «el mimetismo es tan fuerte que se asemeja al plagio» (1992, p. 373). 
su mujer e hijo ${ }^{97}$. El personaje de Pajarito bien podría ser algún periodista ácrata del momento. Incluso, en un sentido algo paródico, la denuncia en los periódicos de Pajarito recuerda vivamente las denuncias que sobre la corrupción policial y los agentes alemanes realizaba el sindicalista Ángel Pestaña en las páginas de Solidaridad Obrera.

Tras el asesinato de Savolta a tiros en su casa, delante de sus invitados, Lepprince asciende a la cúpula de la empresa y cumple su proyectado matrimonio con la hija de éste, María Rosa Savolta. Cuando Savolta cae asesinado, las autoridades detienen, juzgan y ejecutan como responsables a varios anarquistas. Pero el comisario Vázquez, encargado de investigar el caso, desconfia de Lepprince. Es el policía bueno, que trata de averiguar la verdad de los hechos, cuyo celo profesional acaba resultando molesto al poder, que le depura y le traslada a Tetuán. El comisario Vázquez seguirá la investigación del caso aún después de que los supuestos asesinos de Savolta hayan sido ajusticiados. Su alto sentido del deber hará que, incluso después de haber sido alejado de Barcelona, e incluso después de haber dejado de formar parte de la policía, continúe buscando al verdadero asesino de Savolta. Es más que probable que el personaje del inspector Vázquez tenga como referente concreto al comisario Manuel Casal Gómez, autor del libro Origen y actuación de los pistoleros. Como el inspector Vázquez, Manuel Casal denunció y trató de desenmascarar las turbias maniobras del terrorismo patronal en los años del pistolerismo. Ambos acabaron depurados ${ }^{98}$.

Mendoza, que se reconoce muy influido por Pío Baroja ${ }^{99}$, utiliza como narrador principal de la historia a Javier Miranda, un personaje muy barojiano, caracterizado por una abulia que le incapacita para definir su existencia. En su propio nombre simbólico se encuentra la esencia de su personalidad: sólo mira, pero es incapaz de actuar para cambiar la realidad o su propia vida ${ }^{100}$. Miranda recuerda los hechos

97 Su nombre alude, según Ruiz Tosaus, a un pájaro que revolotea por todas partes, pero cuya indefensión e ingenuidad le llevarán a ser aniquilado por un mundo feroz que él conoce bien y ha denunciado.

98 Otro personaje con referentes históricos es el confidente de la policía, Nemesio Cabra Gómez, sometido a una permanente manipulación, tanto por parte de las bandas anarquistas como de la policía, que se convierte en un vagabundo con arrebatos de locura mística. Ruiz Tosaus señala que «el referente real de este personaje está basado en la persona de un confidente de la policía que, según una crónica periodística del año 1918, mató de un tiro a un comisario. Y, como el agresor estaba loco, nunca se supo si fue un acto de demencia o si, simplemente, después de veinte años de chivato, decidió eliminar a la autoridad».

99 «Mi formación literatura viene de Baroja. Yo buscaba una forma de continuar esa tradición, pero actualizándola».

100 Mero espectador, testigo de los acontecimientos, jamás se compromete con nada. Busca algo que dé sentido a su vida pero, atrapado en un medio hostil, en una sociedad que nunca llega a admitirle, se siente inseguro, desorientado, y se ve arrastrado por las circunstancias, ignorante del sentido de sus propias acciones y de su condición de títere. Al igual que los personajes barojianos, es sensible pero también débil. Se define a sí mismo como «un náufrago», un ser humano desarraigado, de ahí su «soledad agónica», su «hastío»; es decir, su malestar existencial, su sentimiento de frustración y de fracaso porque no ha sabido ser ni un héroe, ni un canalla. Miranda es ambiguo y contradictorio. Si por un lado, simpatiza con Pajarito y los argumentos obreristas, al mismo tiempo se deja deslumbrar por el mundo de Lepprince y ve en el empresario la posibilidad de ascenso económico y social. El propio Mendoza le 
en 1927 en sus declaraciones ante un juez americano, casi diez años después de los acontecimientos. La memoria constituye el motor narrativo de la novela.

Mendoza, como Baroja, abomina del terrorismo «blanco» pero también del terrorismo anarquista aunque, como Baroja, siente simpatía por el anarquismo individualista, por aquellos anarquistas que eran vegetarianos, nudistas y querían imponer el esperanto como idioma oficial para crear una hermandad. Él sabe lo que no sabían, aunque intuían, algunos contemporáneos: que el sueño anarquista de la emancipación de las masas no se cumpliría, o al menos no en la forma que sus adeptos esperaban. Las revoluciones obreras simplemente no surgieron, o se produjeron sin éxito en las sociedades avanzadas y el desarrollo capitalista occidental trajo consigo, paradójicamente, la integración mayoritaria de la clase obrera en el sistema.

define así: «Javier Miranda no entiende nada y por eso tiene la ventaja de contar la historia objetivamente». "Está claro que Miranda es un trepador social pero, como es tonto e ingenuo, sigue la trayectoria al revés. El hombre menos preparado para sobrevivir es el único que sobrevive, el más torpe, el más cobarde, el que tiene menos temple es el único que queda vivo. Esto suele suceder en la vida real». Véase, RUIZ TOSAUS: «Sobre los personajes de La verdad sobre el caso Savolta de Eduardo Mendoza», art. cit. 